\title{
Microstructures of shear zones from selected domains of the Western Tatra Mountains
}

\author{
Maciej KANIA ${ }^{1, *}$ \\ 1 Institute of Geological Sciences, Jagiellonian University, Oleandry 2a, 30-063 Kraków, Poland
}

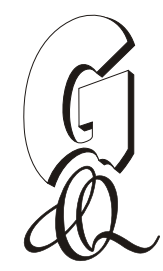

Kania, M., 2015. Microstructures of shear zones from selected domains of the Western Tatra Mountains. Geological Quarterly, 59 (4): 679-699, doi: 10.7306/gq.1243

\begin{abstract}
The paper is focused on the meso- and microstructural characteristics of selected shearing zones in the Western Tatra Mts. The domains of crystalline rocks studied (Długi Upłaz Ridge, Rakoń Mt., Zabraty Ridge and Zabrat' Pass, Wołowiec Mt. Trzydniowiański Wierch Mt., Czubik Mt. and Jarząbczy Wierch Mt.) show evidences of heterogeneous shearing with development of shear zones. Four types of shear zones were distinguished: (1) ductile shear zones in gneisses, (2) brittle-ductile complex shear zones, (3) gneisses with clear later brittle deformation, (4) leucogranites, produced by anatexis with later brittle deformation. The development of these shear zones is characterized by occurrences of various types of fault rocks: cataclasites, S-C cataclasites and mylonites. The different shearing-related rocks and structures are interpreted as an effect of protolith diversity and strain partitioning. Shape-preferred orientation is an important structural feature of all the shearing-related rocks. Kinematic analyses revealed generally a southward sense of shearing documented by structures related to brittle conditions and northwards sense of shearing recognized in ductily sheared crystalline rocks. The time relationships between different shear zone types are discussed, leading to the conclusions that the 1st type of shear zone is pure Variscan, the 2nd type is Variscan with Alpine brittle deformation, and the 3rd and 4th types are mainly Alpine brittle deformations of Variscan syntectonic anatectic leucogranites.
\end{abstract}

Key words: structures, kinematics, shear zones, Western Tatra Mountains.

\section{INTRODUCTION}

Non-coaxial shearing leads to forming shear zones which are localized areas of intense deformation (Ramsay, 1980). Shear zone structures may be developed under different and often variable conditions of pressure and temperature of deformation, stress conditions, and last but not least strain rate (e.g., Berthé, 1979; Simpson and Schmid, 1983; White, 2001). Nowadays, shear zone-related research is an ultimately fast-developing branch of the structural geology, especially with a multi-scale approach to the structures (Passchier and Trouw, 2005; Trouw et al., 2010; Jiang, 2014), analyses of grains shapes and orientation (e.g., Stahr and Law, 2014) and micromechanical modelling of the structures (e.g., a new point of view on the micafish formation by Chen et al., 2014).

This paper is another approach to the meso- and microstructural features of some shear zones observed in selected areas from the Western Tatra Mts. crystalline core. This is a continuation and supplementation of the paper by Kania (2014). That earlier paper was focused on textural features (i.e. grain shape, matrix and grain relationships) of the shear

*E-mail: maciej.kania@uj.edu.pl

Received: February 12, 2015; accepted: June 19, 2015; first published online: July 23, 2015 zone-related rocks. This paper is subjected to the meso- and, especially microstructures. Applying these two methods: grain shape statistics (Kania, 2014) and meso- and microstructures descriptions (this paper), these two papers provide a new description of the shearing-related rock fabric in the Western Tatra Mts., which was also presented in Kania's (2012) Ph.D. thesis. The shape-preferred orientation measurements published in this paper form a link between a morphometric approach presented earlier and structure descriptions presented now.

Whilst the terms "structure", "texture" and "fabric" do not always have clear meanings (e.g., Passchier and Trouw, 2005; Brodie et al., 2007), the term "structure" used there comprises the structure as any geometric and repeating feature in the rock, respectively meso- on a hand-specimen scale, and microon a thin section scale.

The study area (Fig. 1 and Table 1) is located in the upper parts of the Chochołowska and Jarząbcza valleys in the Western Tatra Mountains. This boundary ridge between Poland and Slovakia with a branch towards Trzydniowiański Wierch Mt. is territorially limited, but is an interesting example of a brittle and brittle-ductile non-coaxial shearing record in the Western Tatra crystalline core, due to its complex petrologic inventory and, in consequence, heterogeneity of the observed tectonic strain.

\section{GEOLOGICAL SETTING}

The Carpathians are part of the orogenic belt that extends from the Atlas Mts., through Europe to the Himalaya, which was 


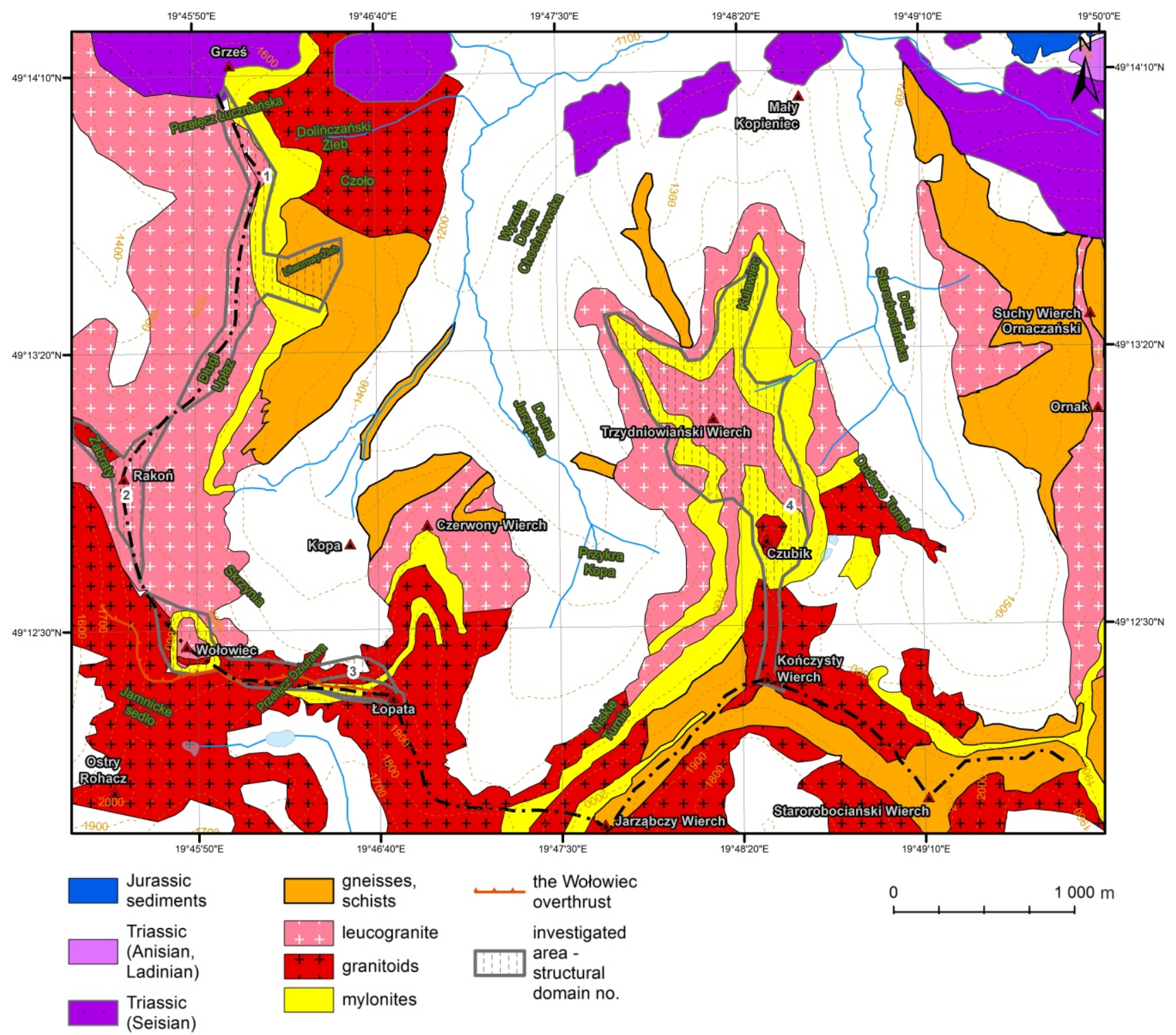

Fig. 1. Geological map of the study area (modified after: Bac-Moszaszwili et al., 1979; Nemčok et al., 1994; Cymerman, 2009)

The analysed domains of fault rocks are marked

formed during Alpine orogeny convergence events. The northern part of the orogeny was deformed in the Cenozoic, the southern part, in the Mesozoic (Minár et al., 2011).

The Western Carpathians are subdivided into the three following zones (e.g., Mahel', 1986; Plašienka, 1995): Outer, Central and Inner Western Carpathians. The highest and the northernmost massif of the Central zone (CWC) are the Tatra Mts., which are one of three crustal-scale super-units (Tatricum, Veporicum and Gemericum). The massif comprise the crystalline core with a para-autochthonous sedimentary cover as well as overthrust sediments of the Fatricum and Hronicum tectono-facial units, forming the Križna (Lower Subtatric) and the Choč (Upper Subtatric) nappes, respectively (Plašienka, 2003; Piotrowska, 2009; Uchman, 2009). The subdivision of the crystalline core into two parts: Western Tatra Mts. and the granitoids of the High Tatra Mt., is well known from the begin- nings of geological investigations in the Tatra Mts. (Uhlig, 1897).

The metamorphic cover of the Western Tatra Mts. embraces a wide spectrum of rocks - according to Skupiński (1975) these are: amphibolites, plagioclase-biotite gneisses, mica gneisses, migmatites and migmatitic gneisses. The gneisses are metasedimentary rocks, with greywacke and claystone protoliths, dated as Late Cambrian maximum age for sedimentation (Kohút et al., 2008a; Gawęda and Burda, 2004). They may have been formed as well during dynamic recrystallisation (mylonitisation) of granitoids (Cymerman, 2009). Some of the gneisses are orthogneisses with a granitic protolith (Gawęda, 2007). The amphibolites are tholeite mid-ocean ridge basalts (MORB) which were intruding during the Paleozoic into the sedimentary complex, and then metamorphosed (Gawęda and Burda, 2004). 
List of analysed locations of shear zones

\begin{tabular}{|c|c|c|c|c|c|}
\hline \multirow{2}{*}{$\begin{array}{c}\text { Structural } \\
\text { domain }\end{array}$} & \multirow{2}{*}{$\begin{array}{c}\text { Location } \\
(\mathrm{P}-\text { Pass [in Polish: Przełęcz], C - } \\
\text { Couloir, R - Ridge) }\end{array}$} & \multicolumn{3}{|c|}{ Averaged geographical position } & \multirow{2}{*}{ Outcrops/sample no. } \\
\hline & & Latitude $\left(49^{\circ} \ldots \mathrm{N}\right)$ & Longitude $\left(19^{\circ} \ldots \mathrm{E}\right)$ & Elevation & \\
\hline \multirow{3}{*}{1} & Łuczniańska $P$. & $13 ’ 59 "$ & 46’00”' & 1600 & $8 / 8$ \\
\hline & Litworowy C. & $13 ’ 32 "$ & $46 \prime 12 "$ & $1500-1700$ & $6 / 6$ \\
\hline & Długi Upłaz R. - N part & $13 \prime 18 ”$ & $45^{\prime} 50^{\prime \prime}$ & 1670 & $6 / 3$ \\
\hline \multirow{3}{*}{2} & Długi Upłaz R. - S part (Siwarne) & $13 ’ 05 ”$ & $45^{\prime} 43^{\prime \prime}$ & 1760 & $3 / 5$ \\
\hline & Rakoń Mt., Zabraty R. & $128^{\prime}$, & $45^{\prime} 29^{\prime \prime}$ & 1860 (1879 top) & $3 / 3$ \\
\hline & Zabrat' P. & $13^{\prime} 15^{\prime \prime}$ & $45^{\prime} 00^{\prime \prime}$ & 1660 & $2 / 2$ \\
\hline \multirow{6}{*}{3} & Wołowiec Mt. N slopes & $121^{\prime} 3$ & $45^{\prime} 44^{\prime \prime}$ & 1800 & $5 / 9$ \\
\hline & Wołowiec Mt. W traverse & $128^{\prime} \prime$ & $45^{\prime} 41^{\prime \prime}$ & $1800-2000$ & $7 / 12$ \\
\hline & Wołowiec Mt. top & $128^{\prime \prime}$ & $45^{\prime} 46^{\prime \prime}$ & 2050 (2063 top) & $1 / 2$ \\
\hline & Wołowiec Mt. SW slopes & $12^{\prime} 21^{\prime \prime}$ & $45^{\prime} 42^{\prime \prime}$ & 2000 & $2 / 3$ \\
\hline & Dziurawe $\mathrm{P}$. & $121^{\prime} 2$ & $46^{\prime} 06^{\prime \prime}$ & 1836 & $3 / 4$ \\
\hline & Łopata N slopes & $12 ' 17^{\prime \prime}$ & 46'38'" & 1875 & $2 / 2$ \\
\hline \multirow{4}{*}{4} & Trzydniowiański Wierch Mt. W slopes & 13 '02”' & $488^{\prime} 10^{\prime \prime}$ & 1685 & $6 / 4$ \\
\hline & Trzydniowiański Wierch Mt. & 13'08'” & $485^{\prime} 15^{\prime \prime}$ & 1730 (1758 top) & $3 / 3$ \\
\hline & Czubik Mt. & $12 ' 44^{\prime \prime}$ & $48^{\prime} 27^{\prime \prime}$ & 1830 (1845 top) & $7 / 7$ \\
\hline & Kończysty Wierch Mt. N slopes & $12{ }^{\prime} 23^{\prime \prime}$ & $48 ' 26 ”$ & 1950 & $4 / 4$ \\
\hline
\end{tabular}

The crystalline complex of the Western Tatra Mountains underwent mid-crustal thrusting which have resulted in the formation of two structural units of inverted metamorphism (Kahan, 1969; Janák, 1994): the upper unit, containing gneisses, migmatites, granitoids and locally amphibolites, and the lower, metasedimentary unit. The metamorphism inversion is a consequence of Variscan tectonic episodes (Fritz et al., 1992) These units, defined originally in the south of the Rohače granodiorite intrusions (the Slovak Republic), were identified in the Polish Western Tatra Mts. as a migmatitic complex of the upper structural unit and a complex of metasedimentary crystalline schists with amphibolites, forming the lower structural unit (Gawęda and Burda, 2004). The metamorphic conditions were: $573-575( \pm 20)^{\circ} \mathrm{C}, 6-8( \pm 1.5) \mathrm{kbar}$ in the lower structural unit (Ornak gneisses); and 660-670 $( \pm 12)^{\circ} \mathrm{C}, 3-5$ kbar for the
Wołowiec-Łopata area gneisses of the upper structural unit (Gawęda and Burda, 2004).

The Variscan igneous rocks are the younger component of the Western Tatra crystalline massif. According to Kohút and Janák (1994), three types of igneous rocks occur in the Western Tatra Mts.: biotite-amphibole-quartz diorites, "common Tatra-type" granite and Goryczkowa-type granites. The most widespread is the "common Tatra-type". The Variscan magmatism was a multistage process with following phases of at least three intrusion events as described by Gawęda (2007), and with anatexis leading to the formation of leucogranitic veins (Kohút, 2000). Table 2 gives the concise information about the Western Tatra granitods. The geochronology of the Tatra Mts. crystalline core is summarized in the Table 3.

Summary of the Western Tatra Mts. granitoids petrography

\begin{tabular}{|c|c|c|c|c|c|c|c|}
\hline \multirow{2}{*}{ Rock type } & \multicolumn{7}{|c|}{ Modal composition [\%] } \\
\hline & quartz & plagioclases & alkali feldspars & biotite & muscovite & amphiboles & accessory minerals \\
\hline Diorite & 10.3 & 37.2 & 0.3 & 12.1 & - & 38.4 & 1.9 \\
\hline Common Tatra-type & 33.1 & 36.8 & 19.5 & 5.4 & 4.0 & - & 1.2 \\
\hline Leucogranite & $10-50$ & $9-64$ & $9-50$ & - & $0-9$ & - & - \\
\hline Rohače-type & $28-37$ & $29-48$ & $10-29$ & $2-7$ & $2-7$ & - & - \\
\hline Goryczkowa-type & 32.2 & 33.4 & 25.7 & 4.0 & 3.4 & - & 1.3 \\
\hline Rock type & \multicolumn{3}{|c|}{ Description } & \multicolumn{3}{|c|}{ Remarks } & References \\
\hline Diorite & \multicolumn{3}{|c|}{ melanocratic diorites } & \multicolumn{3}{|c|}{ occurs locally, not in the study area } & \multirow{2}{*}{$\begin{array}{l}\text { Kohút and Janák } \\
\text { (1994), Gawęda et } \\
\text { al. (2005) }\end{array}$} \\
\hline Common Tatra-type & \multicolumn{3}{|c|}{$\begin{array}{l}\text { medium- to coarse-grained granites, } \\
\text { I/S-type }\end{array}$} & & & & \\
\hline $\begin{array}{l}\text { Orthogneisses with } \\
\text { leucogranite veins }\end{array}$ & \multicolumn{3}{|c|}{$\begin{array}{l}\text { fine to medium-grained granites, in some } \\
\text { areas also pegmatites }\end{array}$} & \multicolumn{3}{|c|}{$\begin{array}{l}\text { by Kohút and Janák (1994) included into } \\
\text { "common type"; anatexis product }\end{array}$} & $\begin{array}{c}\text { Gawęda (2001), } \\
\text { Gawęda and Burda, } \\
(2004)\end{array}$ \\
\hline Rohače-type & \multicolumn{3}{|c|}{ two-mica granodiorite } & \multicolumn{3}{|c|}{ post-collisional or late orogenic provenance } & \multirow{2}{*}{$\begin{array}{c}\text { Kohút and Janák } \\
\text { (1994), Burda and } \\
\text { Klötzli (2007), } \\
\text { Kohút and Siman } \\
\text { (2011) }\end{array}$} \\
\hline Goryczkowa-type & \multicolumn{3}{|c|}{$\begin{array}{l}\text { medium-grained granodiorite with pegma- } \\
\text { tite and aplite veins }\end{array}$} & \multicolumn{3}{|c|}{$\begin{array}{l}\text { the northernmost pluton parts, not in the } \\
\text { study area }\end{array}$} & \\
\hline
\end{tabular}


Summary of the gechronological data for the Tatra Mts. crystalline core

\begin{tabular}{|l|c|c|}
\hline \multicolumn{1}{|c|}{ Tectonometamorphic event } & Age [Ma] & References \\
\hline Protomagmatism of the most Western Carpathians orthogneisses & 500 & Kohút et al. (2008) \\
\hline Oldest Tatra Mts. granitoids (metamorphosed later) & 406 & Poller et al. (2000) \\
\hline Metamorphism (orthogneisses) & 365 & $\begin{array}{c}\text { Poller et al. (2000), Burda and Klotzli (2007), Burda } \\
\text { and Gawęda (2009), Kohút and Siman (2011) }\end{array}$ \\
\hline S-type granitoid intrusion & $360-345$ & Gawęda (2008) \\
\hline Earliest Variscan mylonites (muscovites) & 343 & Deditius (2004) \\
\hline \begin{tabular}{l|c|} 
Leucogranite formation (syntectonic melting of the upper structural \\
unit)
\end{tabular} & 340 & Gawęda (2007) \\
\hline Latest Variscan mylonites (muscovites) & 298 & Deditius (2004) \\
\hline High Tatra granitoid intrusion & $350-337$ & Burda et al. (2013); Poller and Todt (2000) \\
\hline Final uplift (apatite fission tracks) & $15-10$ & Kovač et al. (1994) \\
\hline
\end{tabular}

The final uplift of the Tatra Mts. began during the Late Neogene (e.g., Danišík et al., 2008, 2010, 2011).

\section{METHODS}

The fieldwork was focused on the documentation of the following domains (Fig. 1 and Table 1): (1) northern part of the Długi Upłaz Ridge and the Litworowy Couloir, (2) southernmost part of the Długi Upłaz with the Rakon Mt. and the adjoining Zabraty Ridge to Zabrat' Pass (Slovakia), (3) Wołowiec Mt. massif, (4) Trzydniowiański Wierch Mt.-Czubik Mt.-Kończysty Wierch Mt. ridge. These domains are defined mainly on the contemporary geomorphologic features, which are deeply linked with the geological structure, but also show generally uniform orientations of the kinematic indicators. Structural data include measurements of the structural feature orientations (S and C planes, C' shear bands, lineation and fault planes with slickensides; Lister and Snoke, 1984; Passchier and Trouw, 2005). The kinematics was determined based on the kinematic indicators such as: (1) in the ductile regime: mylonitic foliation with S-C, C' structure, folds, and asymmetric porphyroclasts; (2) in the brittle regime: ridge-in-groove lineations and Y-P-R shear sets (Petit, 1987; Cymerman, 1989; Passchier and Trouw, 2005). These results can be partially misinterpreted due to problems in distinguishing $\mathrm{S}, \mathrm{C}$ and $\mathrm{C}^{\prime}$ elements from the $\mathrm{R}$, $R^{\prime}$ and $P$ (Katz et al., 2004) mesofaults in the rocks deformed in brittle-ductile conditions. Lower-hemisphere equal area projections were always used for presentation of the obtained data.

The microstructures were described from 45 thin sections made with unoriented samples. These sections were cut normal to the foliation and parallel to the stretching lineation (the $X-Z$ section of the finite strain ellipsoid).

Generally, the fault-rock terminology after Brodie et al. (2007) was applied. This classification allows naming some foliated rocks as cataclasites, and includes tectonic breccias and gouges into the group of cataclasites. The term S-C mylonites was introduced by Berthé et al. (1979), and extended to the cataclastic (non-foliated) rocks by Lin (1999). The subdivisions of cataclasites and mylonites into proto-, meso-, and ultragroups according to the classification of Woodcock and Mort (2008), which is the revized classification of Sibson (1977), is based mainly on the grain and matrix proportion as well as the presence of foliation. The rocks with recrystallised grains are called "blastomylonite" in these classifications. The term 'phyllonite' is sometimes regarded as an anachronism, however is defined in the IUGS recommendation as mylonites with a high content of phyllosilicates, with phyllite-typical shine (Brodie et al., 2007). As the relation of the described rocks to the fault zones is not always clear, especially, when deformation are ductile, therefore the term "shearing-related" rocks will frequently be in use.

Shape-preferred orientation degree determination. The presence of shape-preferred orientation structures is generally described with the qualitative terms. However, this preferred orientation is often observed in non-foliated rocks, like cataclasites, that is why the term "S-C cataclasite" was introduced (Lin, 1999; 2001).

The parameter allowing determining this preferred orientation can be relative orientation of grains in the rock section. This parameter $(\varphi)$ is defined with the formula (Roduit, 2007):

$$
\varphi=\frac{180^{\circ}}{2 \pi} \tan ^{-1}\left(\frac{2 \mu_{11}}{\mu_{20}-\mu_{02}}\right)
$$

where: $\mu_{02}, \mu_{11}, \mu_{20}$ are the momentum describing ellipse-derivative shapes.

This was determined during image analyses of the mosaics of thin section photos, with no less than 50 quartz and feldspar grains measured in 13 samples representing different rock types (the same photos which were used for morphometry in Kania, 2014). Then, the statistical concentration coefficient was determined for each of the samples with the following formula (Krawczyk and Słomka, 1994):

$$
L=\frac{\sqrt{\left(\sum_{i=1}^{n} \sin \varphi_{i}\right)^{2}+\left(\sum_{i=1}^{n} \cos \varphi_{i}\right)^{2}}}{n} \times 100 \%
$$

where: $L$ - concentration coefficient, $\varphi$ - grain relative orientation, $n$ - number of grains analysed.

The $\varphi$ values were multiplied by 2 because the $L$ coefficient can be determined correctly when the angle is between 0 and $360^{\circ}$. 
It was tested, that for the random generated sets of the angles, the $L$ coefficient was always less than $10 \%$, thus higher values can be interpreted as the shape-preferred orientation indication.

\section{STRUCTURAL DOMAINS}

DOMAIN 1: THE NORTHERN PART OF THE DŁUGI UPŁAZ RIDGE WITH ITS EASTERN SLOPES

Geological setting. The contact zone between crystalline rocks and Triassic quartzite is located about $200 \mathrm{~m}$ northwards above the Łuczniańska Pass. The northernmost part of the crystalline complex is composed mainly of leucogranites and granodiorites, but also gneisses. Nemčok et al. (1994) mapped there amphibolites that, in fact, seem to be hardly found in this area. According to Gawęda (2001) the Łuczniańska Pass is built of upper, mainly migmatitic, structural unit. However, the structure of this area is probably more complicated, embracing at least two tectonic flakes with fault rocks in between (Cymerman, 2009). Migmatites do not seem to be the constituent part of the massif.

Continuing to the south, the Długi Upłaz Ridge with the Litworowy Couloir on the eastern slopes was mapped as composed of granitic gneisses (Guzik, 1959), leucogranites (forming veins or lenses) with greisens or mylonites and a metamorphic complex below (Skupiński, 1975; Bac-Moszaszwili et al., 1979) or migmatised gneisses of the upper structural unit with leucogranites below (Gawęda, 2001). The role of the tectonic processes in the contact zone was emphasized by Skupińsk (1975) and Cymerman (2009; see also Piotrowska et al., 2007).
Shearing-related rocks and mesostructures. The first, not distinctive brittle structures (rare mesofault planes) are observed about $100 \mathrm{~m}$ to the south from the Łuczniańska Pass. Then, continuing with the ridge to the south, ca. $200 \mathrm{~m}$ from the Łuczniańska Pass, the fault rocks form four bands, tens of metres in width (Fig. 2A), interlayered with undeformed or slightly deformed granitoids. These bands are outcropped mainly along the tourist path. The deformed zones comprise mainly brittle deformed leucogranites, protomylonites (Fig. 2B, C) and/or local mesomylonites with sericite matrix.

The Czoło is a short, flat ridge branched to the east. This ridge is built mainly of granodiorites, however, above this ridge, on the morphological flattening, clearly folded schists are observed. The cuspate-lobate folds are a few centimetres in amplitude and wavelength. Their axes are subhorizontal, generally trending towards the WSW. The change in foliation parameters between this location and the location above the Litworowy Couloir, suggests that higher-order folds are present here.

The few contact zones between mylonitic schists and less-deformed rocks were observed. These contacts are often outlined with pegmatite veins (a pegmatitic form of the leucogranites) or just quartz veins. A few metre wide quartz veins are observed also in the eastern slopes of the ridge. The internal structure of these veins is characterized by sub-horizontal layering and cut by a SW-dipping joint system. Above, on the trail, fragments of small fold hinge zones were found.

Generally, shear zones-related mylonitic rocks form an anastamosing network in this area due to deformation partitioning in a relatively small scale. The mylonites are cut by protocataclasites, or, less common mesocataclasites with a leucogranitic protolith. The granitoids located between more intensely deformed bands are leucogranites, locally with protocataclasis features. The same is true for the granodiorites
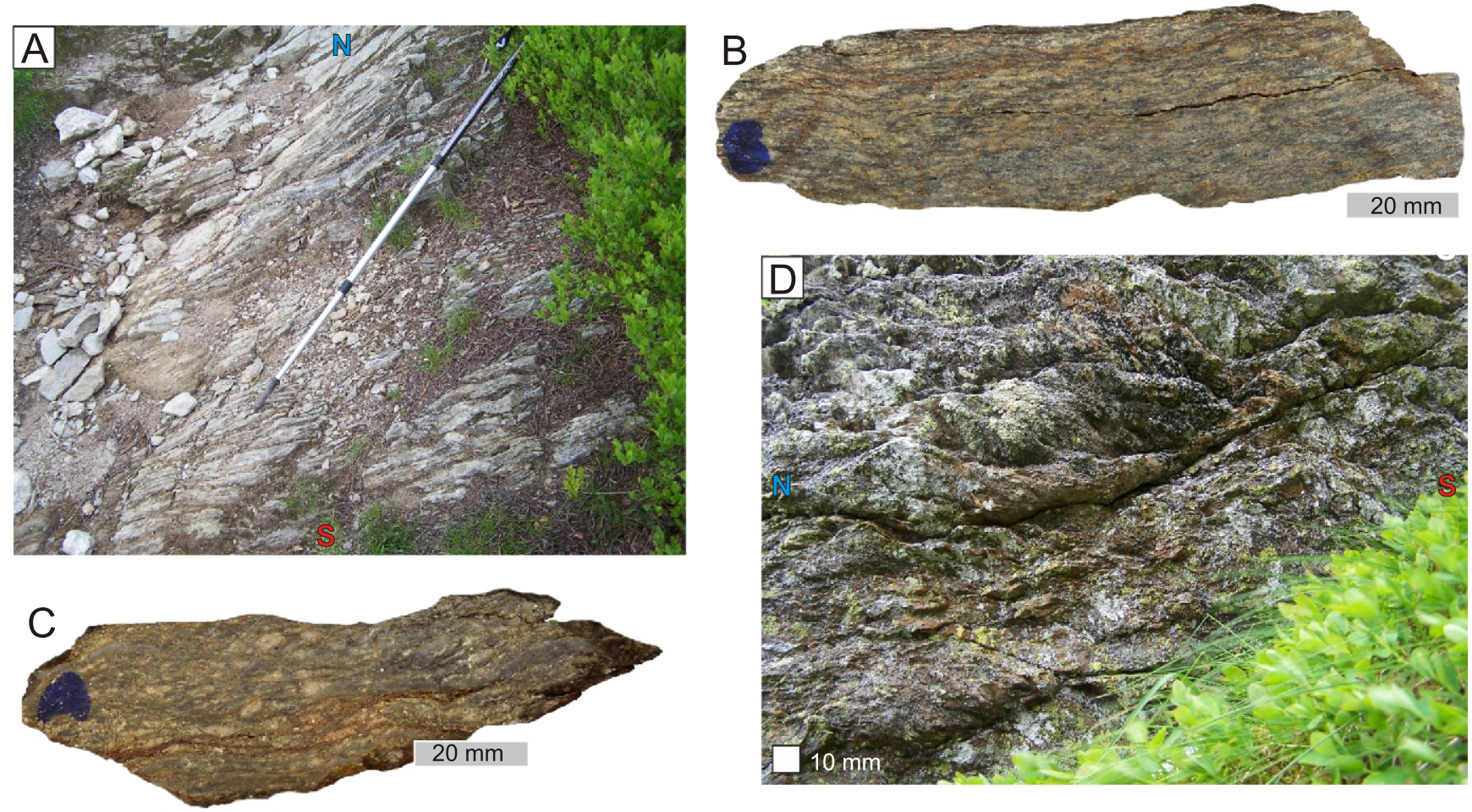

Fig. 2. Examples of shear zones and rocks of domain no. 1

A - mylonite shear zone on the Łuczniańska Pass; B - complex brittle-ductile shear zone in the Litworowy Couloir; C - mylonitic gneiss, Długi Upłaz Ridge; D - mylonite, Długi Upłaz Ridge 

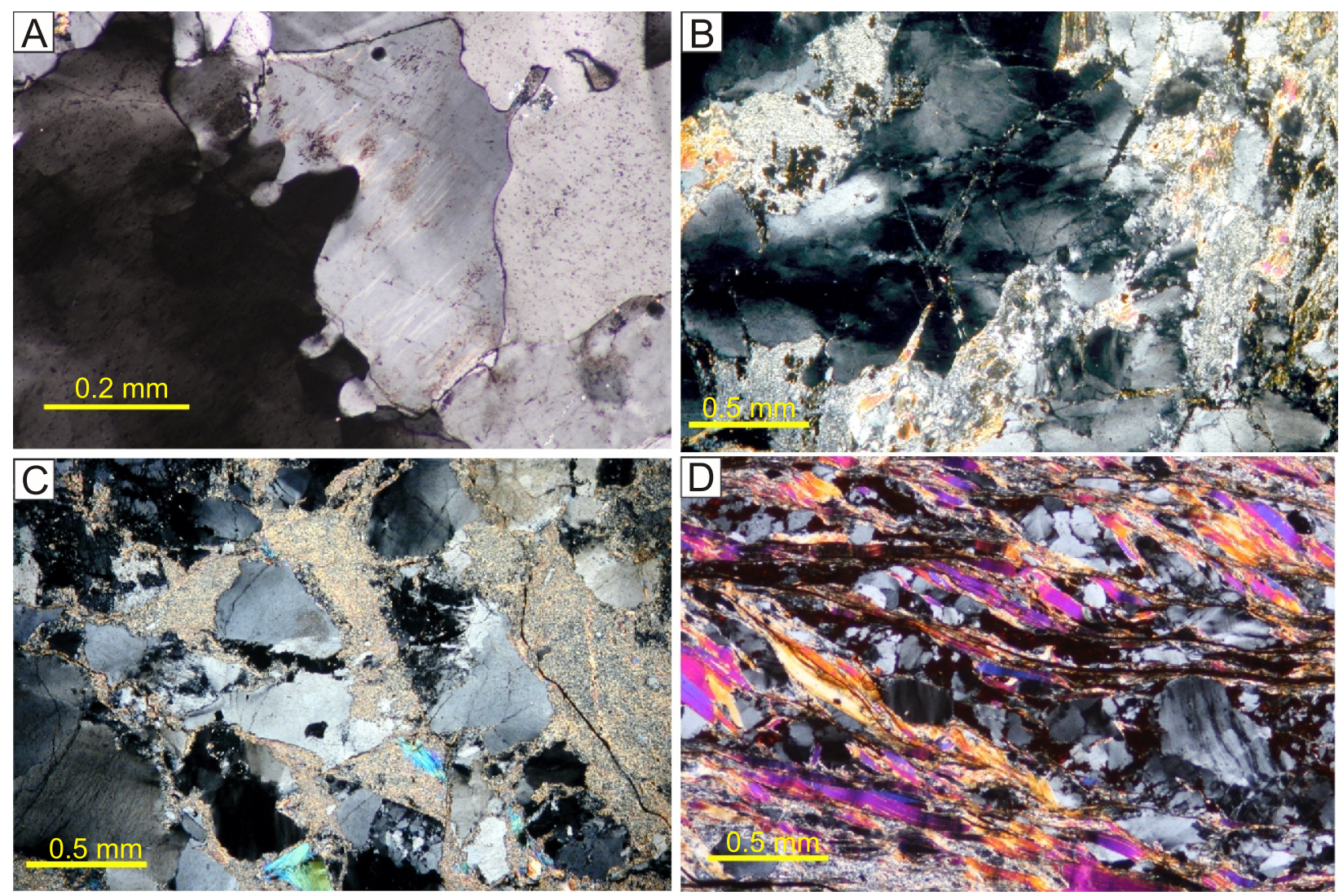

Fig. 3. Examples of microstructures from domain no. 1

A - bulging-type (BLG) of quartz dynamic recrystallisation, protocatalasite, Długi Upłaz Ridge; B - crystaloplastic and brittle deformation of quartz, note the conjugate joints, Długi Upłaz Ridge; C - ultracataclasite, note the high matrix content, Długi Upłaz Ridge; D - sinistral shear zone in mylonite, note the S- and C-foliation structures and muscovite, pointed fish; all photos in crossed polarizers

forming the short Czoło Ridge. Non-deformed or slightly deformed leucogranites show only weak magmatic foliation, whilst shearing foliation in protomylonites is defined by elongated biotite and chlorite aggregates, as well as quartz shape-preferred orientation forming ribbons, but without distinct dynamic recrystallisation features. At some locations, mica forms bands with an S-C fabric.

The Litworowy Couloir is the place, where a vast packet of shearing-related rocks is outcropped (Fig. 2D). Above the Couloir, slightly deformed leucogranites or leucogranitic gneisses occur in the Długi Upłaz Ridge. The most common type of fault rocks there are cataclastic breccias. Protocataclasites occur at some locations. The boundaries between these rock-types are not sharp. Crushed and faulted grains, observed on a microscale, are mainly feldspars. The quartz grains show mainly weakly ductile deformation, however bulging-type dynamic recrystallisation structure is locally observed. Below, in the couloir, there is a zone of fault rocks, about $80 \mathrm{~m}$ in width, between altitudes of ca. 1560-1640 m. In the uppermost part of the Litworowy Couloir, protocataclasites with a small amount of sericite matrix, gradually pass into a heterogeneous packet of mesocataclasites and ultracataclasites. In the uppermost part of the Litworowy Stream brittle-deformed fault rocks (meso- and ultracataclasites) coexist with packets of mylonitic schists and phyllonites.

The described complex is cut by numerous mesofaults. The density of fault planes increases downwards and reaches $>100$ for $1 \mathrm{~m}$ of the profile. This results in rock schistosity.
Generally, the fault rock complex observed in the Litworowy Couloir forms an almost horizontal brittle and brittle-ductile shear zone. The width of this zone is difficult to be precisely determined, but can be estimated as $80-100 \mathrm{~m}$. The core of the shear zone is a complex of ultracataclasites, mylonites and ultramylonite, $\sim 30 \mathrm{~m}$ wide. The surrounding damage zone comprises mainly mesocataclasites with brittle deformation fading out upwards. There are no outcrops of this zone in the northern branch of the Litworowy Couloir, where only slightly brittle-deformed granodiorites are present.

Microstructures (Fig. 3). The mylonitic foliation is expressed by C-foliation bands composed of muscovite, biotite, and chloritised biotite with oblique S-foliation bands. Quartz grains show undulose extinction and lobate shapes. Generally, quartz grains are elongated in the C-foliation direction. However, sometimes short quartz veins, oblique to the C-foliation and without shape-preferred orientation, are observed. When rocks are foliated, there are typically no brittle deformation features, also feldspars show no deformation.

In some areas, the foliation of mylonites shows some irregularities in direction. However, these irregularities seem to be developed also in the ductile conditions, and can be an effect of stress reorientation during deformation.

Above the Litworowy Couloir, protocataclasites and mesocataclasites dominate in the Długi Upłaz Ridge, in some places turning into ultramylonite (phyllonite) zones. These zones are up to tens of centimetres in width. Occasionally, ultracataclasites with traces of total crushing of the protolith, but without traces of the cataclastic flow (slides or rotations) are 
present in the Długi Upłaz Ridge. The microstructure of these rocks shows a "matrix-supported" type. Occasionally, muscovite with relics of ductile deformation occurs. These grains are randomly oriented and brittle-disintegrated. Quartz with traces of brittle and ductile deformation sometimes show bulging-type dynamic recrystallisation (BLG, Fig. 3A). The locally observed zones of sericite concentration in matrix can be possibly areas of initially forming porphyroclasts (formation of blastomylonites). In some areas, brittle deformation systems are visible, expressed by parallel-oriented edges of angular grains (interpreted as the $Y$ system) and wide short cracks (tensional cracks, T system). In addition, a few milimetres long quartz veins are oriented parallel to the $T$ system. The conjugate shear has been identified, often overprinting crystaloplastic deformation in quartz (Fig. 3B).

There are two types of ultracataclasites on the ridge over the Litworowy Couloir: typically, non-foliated cataclasites (Fig. 3C) and S-C cataclasites. This second type is characterized by scattered directional structures, such as elongated grain aggregates or mica fish. However, these structures do not form distinct foliation.

The S-C fabric is very well-developed with distinctive, elongated muscovite fish, most similar to group 2 (lenticular fish with points inclined in the foliation direction) in the Grotenhuis et al. (2003) classification. Below this area, narrow sheared mica bands (about $1 \mathrm{~mm}$ wide) and quartz "ribbons" structures parallel to the S-foliation planes are observed in the cataclasites with mylonitic foliation features (S-C cataclasites). These structures are oriented concordantly to the S-foliation planes.

The foliation of ultramylonites (phyllonites) is defined mainly by muscovite fish and ribbons of oblique quartz crystals (Fig. 3D). In the pure quartz layers, oblique foliation disappears, however shear planes according to the C' shear bands are present. There are small areas of major reorientation of the foliation planes (up to $40^{\circ}$ ) as well as wide fracture zones with chaotically rotated micas.

Plagioclases do not show any structural coincidence with foliation, but show some brittle deformation (microfaults). Locally, layered fine-grained sericite matrix is present, forming narrow bands.

Kinematics. The dominant kinematics recorded by the brittle structures in this area is the thrusting top-to-the-SSE, S and SSW on the faults dipping at moderate angles (ca. 30-40 ) mainly to the $\mathrm{S}$. The second, less numerous set, composed of

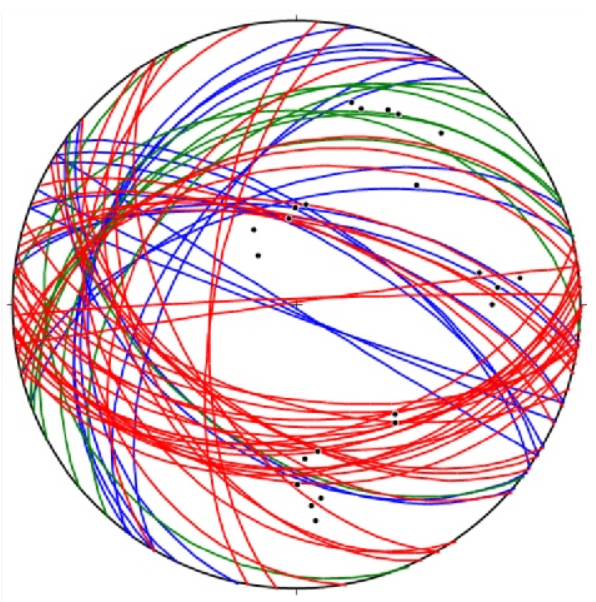

Fig. 4. The orientation of S-foliation planes (red arcs), C-foliation planes (blue arcs), C' shear bands (green arcs) and mineral grain lineation (points) in domain no. 1
E- or W-dipping faults records the SW or NW thrusting. The fault rocks in this area are strongly heterogeneous. Gradational transitions between different types of rocks can be observed with a general trend of tectonic deformation degree increasing downwards.

The kinematic indicators (Fig. 4) for the ductile features were measured mainly in the phyllonites. The mean orientation for the $\mathrm{C}$ planes is $359 / 60$. The $\mathrm{S}$ planes generally steeply dip to the SE and SSE. The relationships between foliation planes, as well as other indicators observed in the oriented thin sections, reveal top-to-the-north tectonic transport directions.

DOMAIN 2: THE SOUTHERNMOST PART OF THE DŁUGI UPŁAZ RIDGE, RAKOŃ MT. AND ZABRATY RIDGE

Geological setting. The southern part of the Długi Upłaz Ridge is composed of granitic gneisses (Michalik and Guzik, 1959) and pegmatoidal granites (Skupiński, 1975). Gawęda (2001) mapped there alaskites and overlying migmatite and gneisses complex of the upper structural unit. The southernmost section of the Ridge, just below the Rakon Mt. summit, is composed of leucogneisses, by some authors mapped also as leucogranites (Michalik and Guzik, 1959; Skupiński, 1975; Nemčok et al., 1994). Cymerman (2009) noted that gneisses gradually pass eastwards into lit-par-lit migmatites. There, and on the Rakoń Mt. as well, Gawęda (2001) mapped rocks of the upper structural unit.

The Rakoń Mt. topmost part comprises an upper gneissic complex above leucogranites, with a zone of strongly deformed gneisses in between (Cymerman, 2009). Skupiński (1975) and Bac-Moszaszwili et al. (1979) mapped there only leucogranites (alaskites). On the geological map by Nemčok et al. (1994), the Rakon Mt. and the northeasterly adjoining Zabraty Ridge, are marked as composed partially of gneissic leucogranites and Rohače-type granitoids in the topmost part.

Shearing-related rocks and mesostructures (Fig. 5). In the northern part of Siwarne (part of Długi Upłaz), the leucogranites are weakly deformed. Weakly rocks gradually pass into tectonic breccias and protocataclasites. The crushed minerals are represented mainly by feldspars which are only fractured, or locally show micro-scale slip surfaces. Cataclastic matrix is almost completely absent. Quartz grains show weak crystaloplastic deformation expressed by undolose extinction, or in some samples - by bulging-type dynamic recrystallisation.

The deformation intensity increases to the south, where up to a few metres wide zones of mylonitic schists with irregular graphite bands exist, but without distinctive concentrations of micas. These rocks gradually pass into laminated and augen laminated gneisses, but pegmatite and quartz veins are observed between schists and gneisses.

Just below the Rakon Mt., fault rocks are outcropped in the NW direction and comprise protocataclasites and mesocataclasites (Fig. 5A) as well as S-C cataclasites. These rocks coexist with mesomylonites and ultramylonites. Generally, co-occurrence of the brittle and brittle-ductile deformation structures is typical in this area. Undoubtedly, distinguishing between the ductile $\mathrm{C}$-type shear planes and Y-type mesofaults is difficult.

The Zabraty Ridge is characterized by the occurrences of gneisses in the upper part, passing gradually downwards into a ultramylonite/ultracataclasite complex. In fact, the area of the Zabrat'Pass is the place where most advanced deformation occurred with ultramylonites (Fig. 5B) and ultracataclasites interchanging in the relatively small area. 

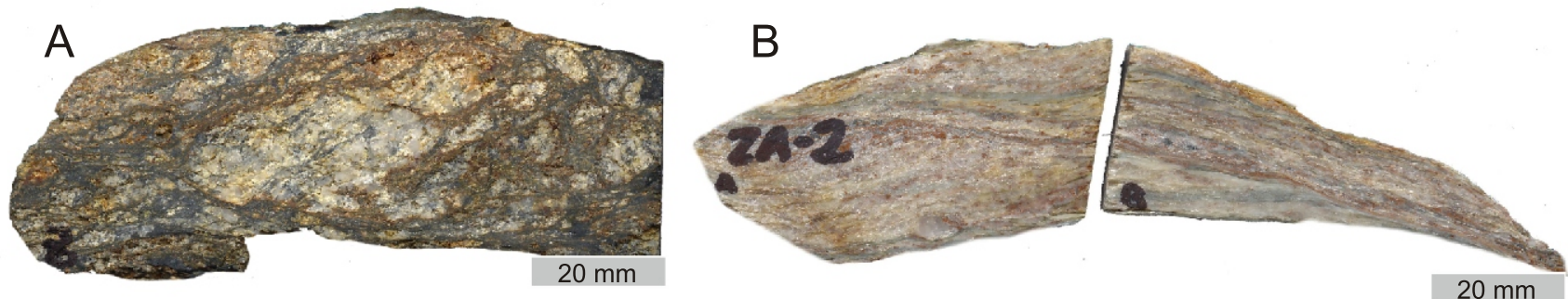

Fig. 5. Examples of hand-specimens from domain no. 2

A - Rakoń Mt. cataclasite with graphite bands; B - Zabrat' Pass ultramylonite

Microstructures (Fig. 6). The proportion of the moderately and strongly deformed rocks (meso- and ultracataclasites) on the weakly deformed rocks (protocataclasites) increases westwards. The ultracataclasites form layers with the maximum width of $\sim 10 \mathrm{~cm}$, and are cut with numerous conjugate shears. Graphite bands also occur in the form of up to $1 \mathrm{~mm}$ veins (Fig. 6A). In the mylonites, S-C-foliation structures are clearly recognizable.

Below the Rakon Mt. on the Zabrat' Pass, very well-developed mylonites with rotational core - mantle structure porphyroclasts were found (Fig. 6C). Fine-grained quartz aggregates on the sericite-dominated background emphasize the C-foliation planes, together with micas, which show no sigmoid shapes. One-sided syntaxial pressure fringes (Bons et al., 2012) are well-developed on opaque minerals (Fig. 6B). As noted above, the deformation style locally changes dramatically in the small scale (Fig. 6D), with sharp boundaries between.

Kinematics. The main set of thrusting faults has the top-to-the-S kinematics. These faults dip mainly to the N, NNE and $S$ at moderate angles. The second set of faults is composed of moderate to steep faults dipping to the $S$ with top-to-the NE sense of shearing recorded.

In the predominant ductile deformed zones, S-C-foliation is not homogeneous (Fig. 7). The $\mathrm{C}$ planes dip at low and moderate angles to the ENE, or at steep angles to the NW and NNW. The S planes dip to the E, ESE, and SE at moderate angles. The spatial relationships of the $C$ and $S$ planes record a dominant tectonic transport direction top-to-the-NNE and NE. The same is proved by the C' synthetic shears dipping to the NE, as well as by orientation of porphyroclasts and mica fish in oriented thin sections.

\section{DOMAIN 3: THE WOŁOWIEC MT. MASSIF}

Geological setting. The Wołowiec Mt. massif (Fig. 8) is composed of granitic gneisses and gneisses (Michalik and Guzik, 1959). Below the metamorphic complex, leucogranites with amphibolite inclusions occur. Skupiński (1975) mapped there a single horizon, tens of metres wide, of "tectonic greisenisation". This zone is marked also by Bac-Moszaszwili et al. (1979) as mylonites. However, Żelaźniewicz (1996) stated that these mylonites (as well as mylonites mapped by those authors in other areas) form numerous en-echelon low-angle zones instead of continuous horizontal outcrops. Cymerman (see Piotrowska et al., 2007) mapped a band of cataclastic rocks on the NW Wołowiec Mt. slopes, and interpreted it as a basement of one of thrust-sheets building the Wołowiec Mt. massif. Lower parts of the SW and SE slopes of the Wołowiec Mt. and the area of the Jamnicka Pass are composed of Rohače-type granodiorites (Nemčok et al., 1994). Gawęda
(2001) included the Wołowiec Mt. into the upper structural unit but marks a few SW-NE narrow mylonitic zones cutting the upper structural unit, alaskites and the lower structural unit. The shear zone-related micas were dated by Deditius (2004), revealing $343 \pm 13$ to $298 \pm 11.3 \mathrm{Ma}\left({ }^{40} \mathrm{Ar} /{ }^{39} \mathrm{Ar}\right.$ method on muscovites), and interpreted as a product of two ductile deformation events: older, related to overthrusting of the metamorphic complex, and younger, related to the Rohače-type granodiorite intrusion.

The contrasts in the Wołowiec Mt. massif lithology are strongly linked with geomorphological features, which is marked i.e. by steep rocky slopes in the southern part of the massif.

Shearing-related rocks and mesostructures (Fig. 9). The occurrences of fault rocks on the $\mathrm{N}$ and NW slopes of the Wołowiec Mt. begin in the vicinity of the border pole no. 249/5 and continue southwards to the top of the massif. Along the touristic pathway, zones of cataclasis can be detected basing on the fragments found on the ground. These fragments are weakly deformed leucogranites and granodiorites, alternating with granitic gneisses, locally folded (Fig. 9A). Biotite-rich S-C cataclasites were also found. Pegmatites are also observed in this area.

The eastern slopes of Wołowiec Mt. are very steep, often vertical, and therefore difficult to access. However, in the rock fragments found below these walls (Skrzynia, Skrajniak), granodiorites and granodiorite or leucogranite-based cataclasites can be often found (Fig. 9B).

In trenches cutting the top of the Wołowiec Mt., mesocataclasites with a leucogranitic protolith occur. Numerous brittle shear planes, forming a typical Y-P-R shearing system, cut these rocks.

Numerous, good quality outcrops of the fault rocks are located on the NW and W slopes of the Wołowiec Mt., in the territory of the Slovak Republic. Along the patch traversing the topmost parts and branching from the touristic pathway at an altitude of ca. $1835 \mathrm{~m}$, there are four zones of weak to moderate cataclasis of the leucogranites and granodiorites.

A well-outcropped complex of the fault rocks can be observed on the W slopes of the Wołowiec Mt. along an unofficial touristic path at altitudes of ca. 1900-1950 m. At least four narrow zones of mylonites and phyllonites, up to tens of $\mathrm{cm}$ in width, occur there. Up to $20 \mathrm{~m}$ wide bands of cataclasites are present in between. The protolith of the cataclasites was mainly granodiorite what is proved by their mineral composition. At some places, mesocataclasites pass into ultracataclasites.

On the SW slopes of the Wołowiec Mt. (south of the Wołowiec-Jamnicka Pass touristic pathway) a few niches with meso- and ultracataclasite outcrops are present. Locally, bands of quartz and mica mylonites or mylonitic schists and phyllonites 

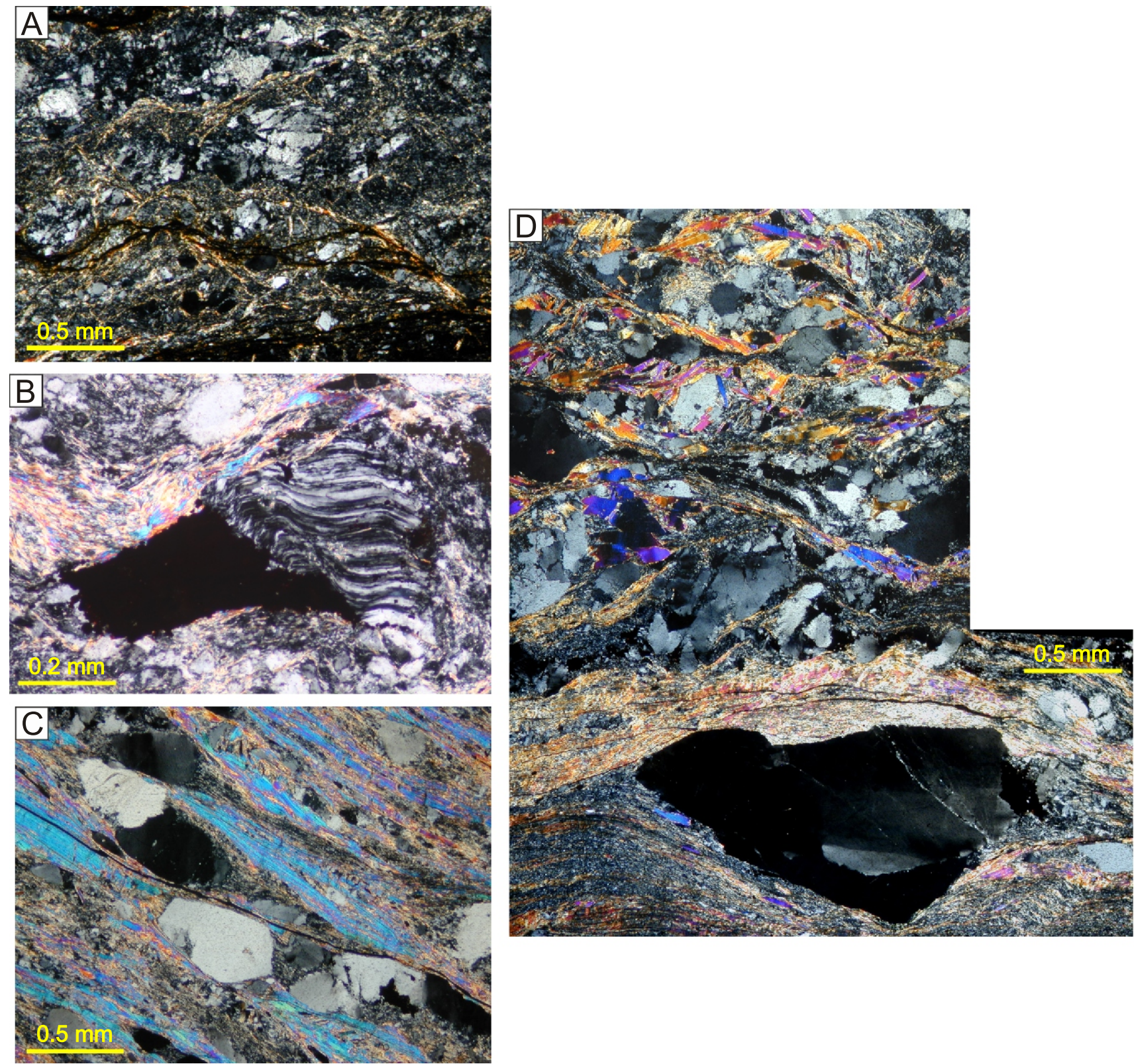

Fig. 6. Examples of microstructures from domain no. 1

A - catalasite from the Rakon Mt. with a system of joints filled with sericite and a graphite band (lower right corner); B - fringe structure in the pressure shadow of an opaque mineral grain (probably hematite); C - quartz pophyroclasts in ultramylonite from the Zabrat' Pass; D - sharp border between textural types observed in the shear zone on the Zabrat' Pass: lower part - ultramylonite, upper part - protomylonite; all photos in crossed polarizers

Fig. 7. The orientation of S-foliation planes (red arcs), C-foliation planes (blue arcs), C' shear bands (green arcs) and mineral grain lineation (points) in domain no. 2

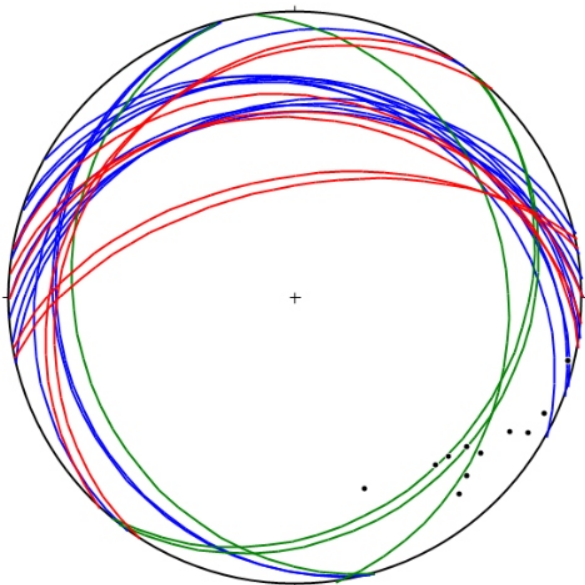




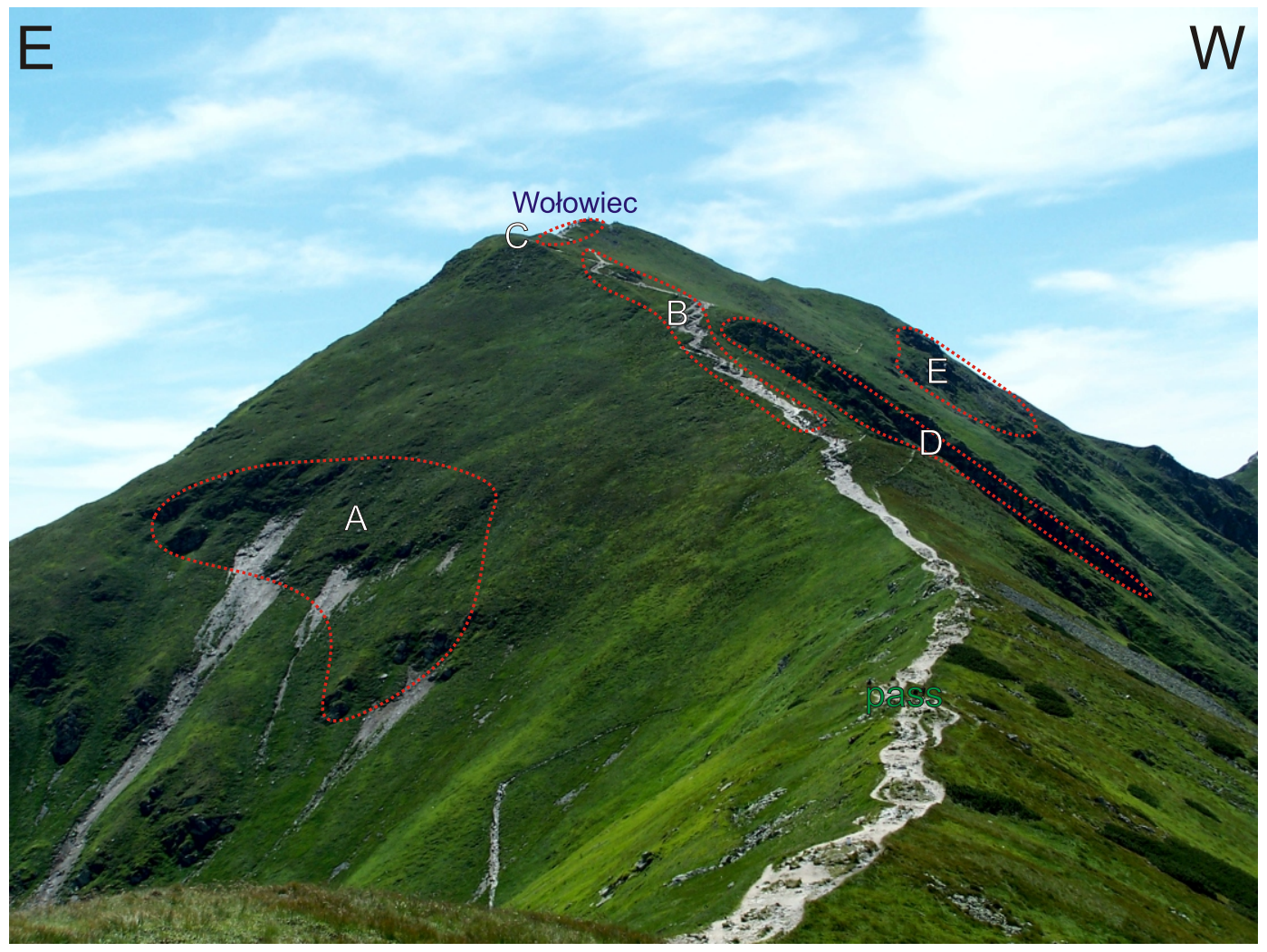

Fig. 8. The general view of domain no. 3, northern part

A - shear zones on the almost vertical Wołowiec Mt. wall; B - leucogranite/cataclased leucogranite-dominated zones; C - the Wołowiec Mt. top, with cataclased granodiorites; D, E - complex shear zones on the western slopes

with graphite are also observed. The protolith of the cataclasites was Rohače-type granodiorite.

The rocky part of the main Western Tatra Mts. Ridge, east of the top of the Wołowiec Mt., is an area of shear zone with complex lithologies. Below an altitude of ca. $1900 \mathrm{~m}$, packets of crystalline (sericite, biotite, sillimanite chlorite, epidote-quartz; Fig. 9C, D) schists are present. These rocks can be classified as phyllonites and mylonites with well-developed foliation planes forming schistosity with distinctive asymmetric features like mica fish occasionally with later deformation.

Microstructures (Fig. 10). In the samples from the NW slopes of the Wołowiec Mt., feldspars show features of brittle and brittle-ductile deformation (Williams et al., 2000; Passchier and Trouw, 2005), as well as quartz with traces of dynamic recrystallisation in the subgrain rotation process (Halfpenny et al., 2006), forming aggregates of elongated grains. Sericite matrix is present on the feldspar/feldspar contacts.

The W slopes of Wołowiec Mt. show a complicated pattern of rocks and their microstructures. Mylonites are interchanged with cataclasites, these two fault rock types are difficult to distinguish macroscopically. In addition, a few $\mathrm{cm}$ wide zones of phyllonites occur, especially southwards. In these rocks, S-C mylonitic foliation is well developed in mica: mainly biotite or chloritised biotite-chlorite. Mica fish structures are abundant and show traces of multistage deformation (Fig. 10A, D, E). In addition, sillimanite fibrolite nests are present. They are elongated parallel to the mineral grain lineation on the $S$ planes. Recrystallised quartz forms core-mantle porphyroclasts (Fig. 10B).

Locally, the fault rocks form a kind of tectonic microscale mélange composed mainly of mylonitic sericite matrix, quartz grains with pressure shadows, sheared with numerous shear bands or microfaults.

On the W slopes of the Wołowiec Mt., ultracataclasites are characterized by a high grain to reduced grain matrix content ratio - up to 1:1. Some of the ultracataclasites show weak foliation or matrix layering. Cataclastic breccias or fault gauges locally occur. The main deformation mechanisms observed in the microscale are brittle deformation of plagioclases with intracrystalline slip systems. Further to the south in cataclasites, shear folds and microfolds are also observed (Fig. 10C, D). On the Łopata Mt., deformations are localized in the narrow zones of folded micas and chaotic aggregates of quartz with bulging recrystallisation features and with microscale folds of the recrystallised matrix.

Kinematics. The sense of shearing recorded in the brittle structures is variable, however top-to-the-S thrusting dominates on the relatively low-angle, mostly $\mathrm{N}$-dipping faults. The second set of faults is also characterized by south-dipping shears with top-to-the-N kinematics.

The $\mathrm{C}$ planes in the mylonitic foliation dip to the WSW at low to moderate angles. The S planes dip to the SE and SW at low angles. This records (Fig. 11) the tectonic transport direction top-to-the-WNW-NNW. The same direction is recorded by the C' shear band dipping to the NW at low angles.

\section{DOMAIN 4: TRZYDNIOWIAŃSKI WIERCH MT., CZUBIK MT. AND KOŃCZYSTY WIERCH MT.}

Geological setting. The Trzydniowiański Wierch Mt. (Fig. 12) in its upper part is composed of two leucogranitic packets with gneissic bands in between (Michalik and Guzik, 1959). 


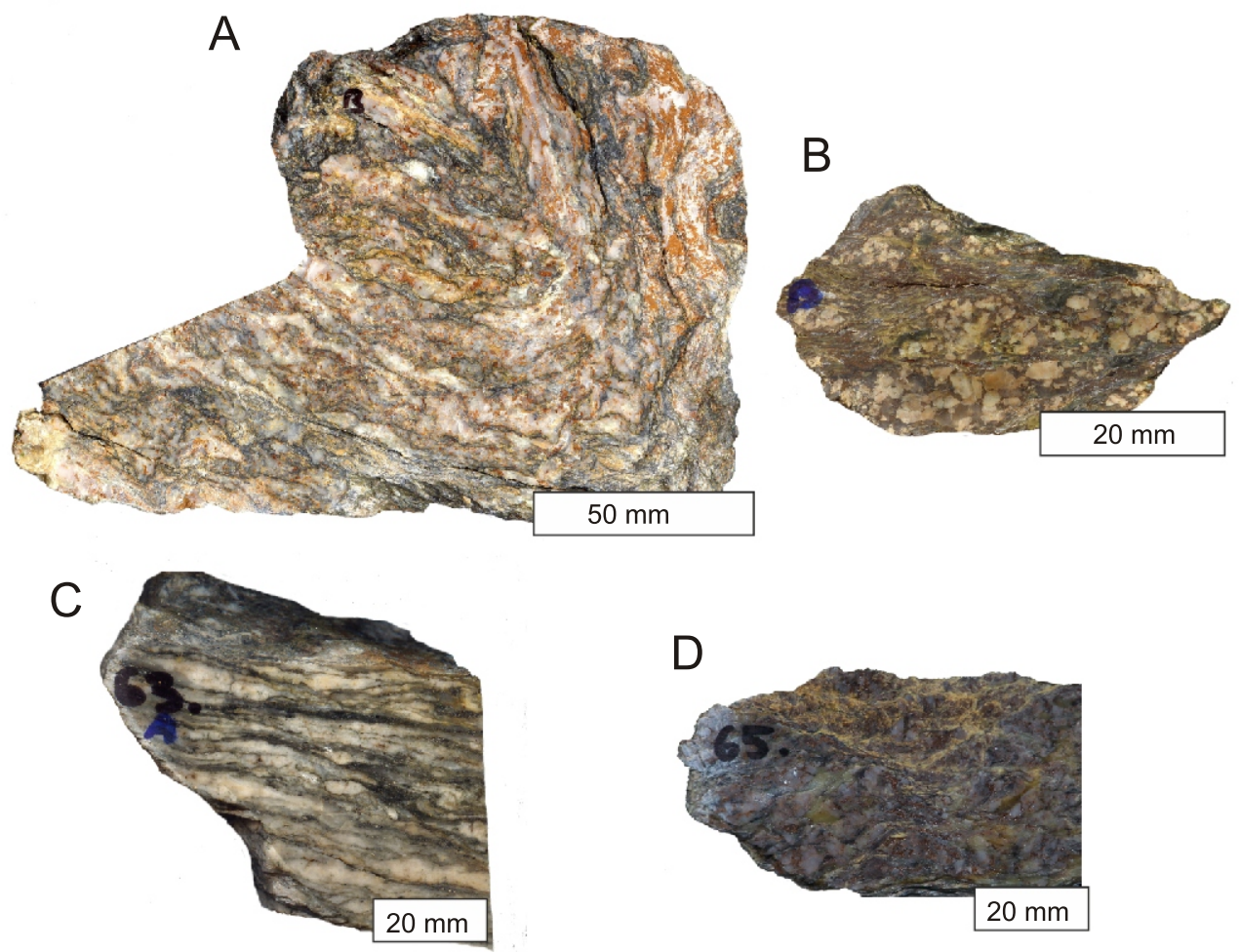

Fig. 9. Examples of hand-specimens from domain no. 3

A - fold developed in the Wołowiec Mt. gneiss; B - cataclasite from the Skrajniak; $\mathbf{C}$ - gneiss with well-visible S-C-foliation and C' shear bands, inducing dextral sense of shearing, from the Dziurawe Pass area; D - blastomylonite from the Łopata Mt.

A mylonitic zone cuts the massif horizontally and is outcropped on the northern slopes (Skupiński, 1975; Bac-Moszaszwili et al., 1979; Gawęda 2001). To the south, the Czubik Mt. topmost parts are composed of granodiorites with granitic gneisses below (Michalik and Guzik, 1959). The contemporary morphology of the slope, with three zones of flattening, can be linked with zones of intensive cataclasis, developed within leucocratic granitic gneisses or leucogranites.

On the eastern slopes, quartz veins are outcropped, similar to these described on the western slope of the Chochołowska valley.

Shearing-related rocks and mesostructures (Fig. 13). The fault rocks occur on the western slopes of the Trzydniowiański Wierch Mt. along the tourist pathway. This area lacks of outcrops, however, some observations are possible.

The deformed rocks in this area are mainly leucogranites (Fig. 13A) or leucocratic granitic gneisses whose gneissic structure is a relic of an older deformation stage (Fig. 13B).

The general trend is an upward increase of non-coaxial shearing intensity. The cataclastic, locally chaotic breccias gradually change to protocataclasites, which is marked by the development of intragranular slip surfaces and results in a block-controlled cataclastic flow regime according to Ismat and Mitra (2005).

To the north, some occurrences of weakly to moderately deformed leucogranites were observed. The lush mountain pine cover does not allow a detailed analysis of these rocks, however, it seems that there are a few up to tens of centimetres wide deformed zones, with non-deformed granite in between.

The area of the Czubik Mt. is characterized by occurrences of the packet of cataclased leucogranites and granodiorites.
The products of deformation of granodiorites are cataclastic (Fig. 13C) and chaotic breccias gradually passing into protocataclasites. On the western slopes of the Czubik Mt. occur up to $20 \mathrm{~cm}$ wide zones of mylonites (mylonitic schists, phyllonites) with millimetre-scale graphite bands.

The intensity of deformation decreases southwards. On the Kończysty Wierch Mt. northern slopes, a number of zones of granodiorite breccias were observed. These are fracture breccias, locally chaotic breccias, without cataclastic matrix.

Microstructures (Fig. 14). In the Trzydniowiański Wierch Mt. area, the characteristic feature is brittle microstructures overprinting ductile ones. These are mainly S-C mylonitic foliation relics; some white micas show traces of brittle deformation. Older, mainly ductile structures, especially mica bands, were later reworked during cataclasis.

In the Czubik Mt., there are cataclasites with the block-controlled cataclastic flow type and small amounts of cataclastic sericite matrix (Fig. 14A). However, the amount of matrix is variable, locally promoting protocataclasites to meso- or even ultracataclasites (Fig. 14B). Quartz is dynamically recrystallised in the bulging recrystallisation process. The granitic gneiss deformation is focused mainly in the mica bands which were sheared and broken, and locally their fragments were rotated. Therefore, the rock has features of tectonic microbreccia. At places, core-mantle rotating porphyroclasts are also present.

In the areas of typical gneisses or mylonites (Trzydniowiański Wierch Mt., Czubik Mt. western slopes), well-developed C' shearing bands are observed (Fig. 14C).

In the Kończysty Wierch Mt. cataclasites intracrystalline fractures in feldspars and undulose extinction in quartz are deformational microstructures observed. 

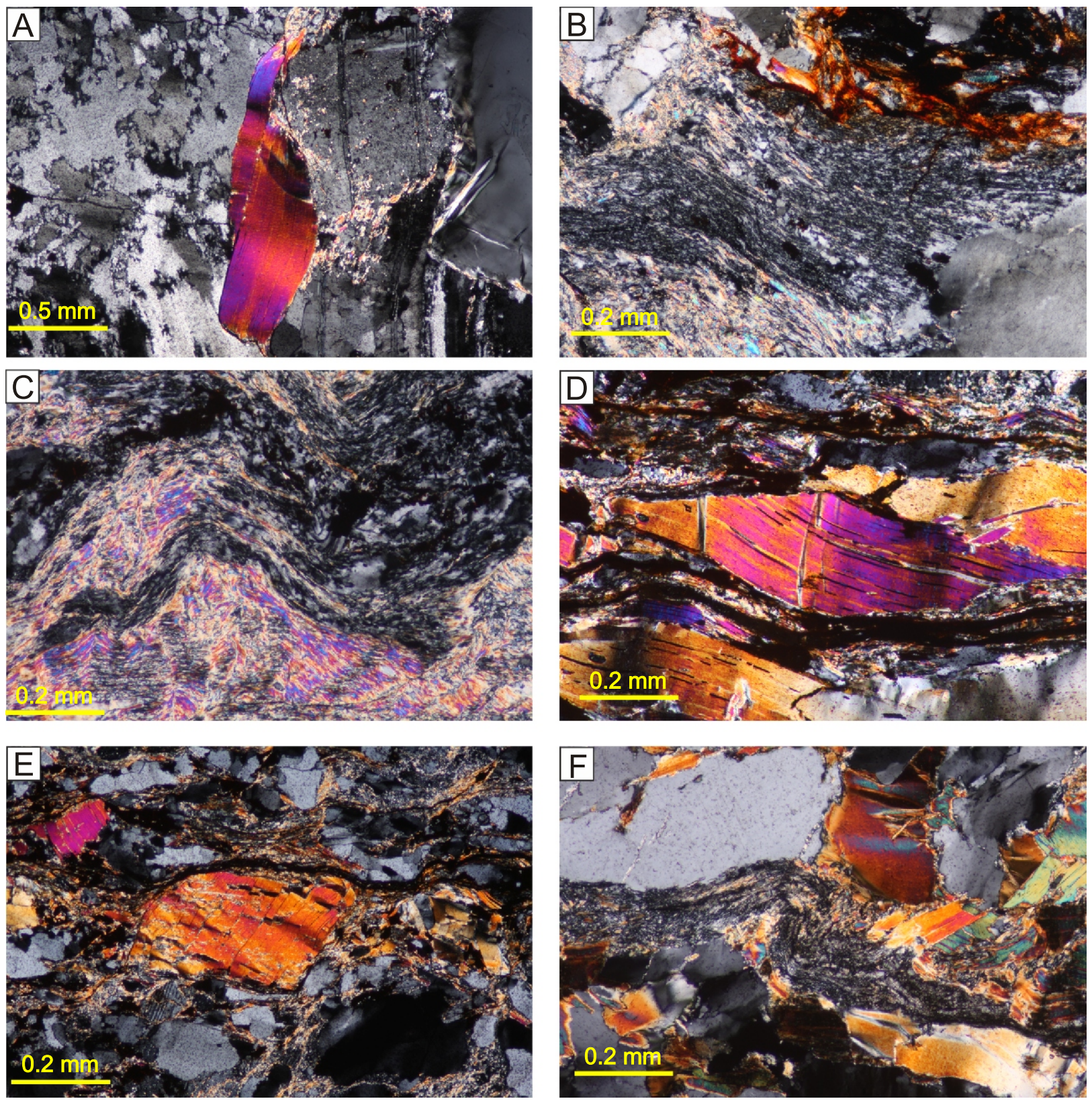

Fig. 10. Examples of microstructures from domain no. 3

A - brittle dextral shearing of muscovite fish - an example of the structures overprinting in cataclasite from the Wołowiec Mt.; B - detailed view of the quartz core-mantle structure: one wing (in the centre) and part of $\delta$-type porphyroclast (on the right), Wołowiec Mt.; C - intrafoliation microfolds in mylonite from the complex brittle-ductile shear zone, Wołowiec Mt.; D - muscovite fish structure indicating sinistral sense of shearing, Dziurawe Pass; E - muscovite fish sheared in brittle conditions, forming domino-type structure; F asymmetric microfolds developed in dextral shearing in the Dziurawe Pass mylonite

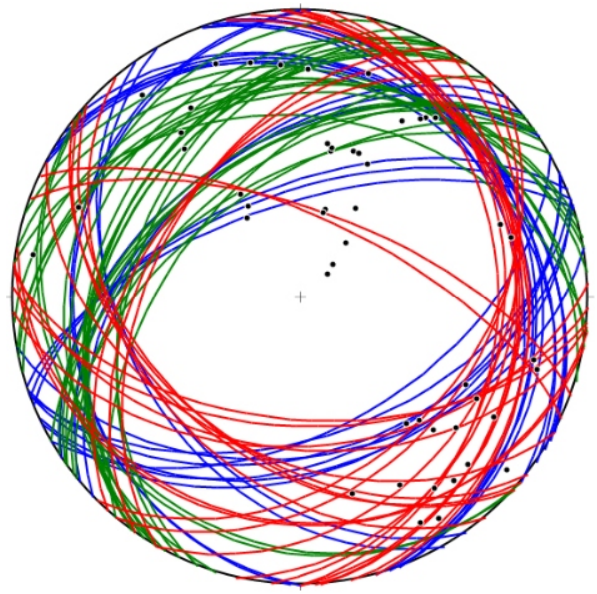

Fig. 11. The orientation of S-foliation planes (red arcs), C-foliation planes (blue arcs), C' shear bands (green arcs) and mineral grain lineation (points) in domain no. 3 


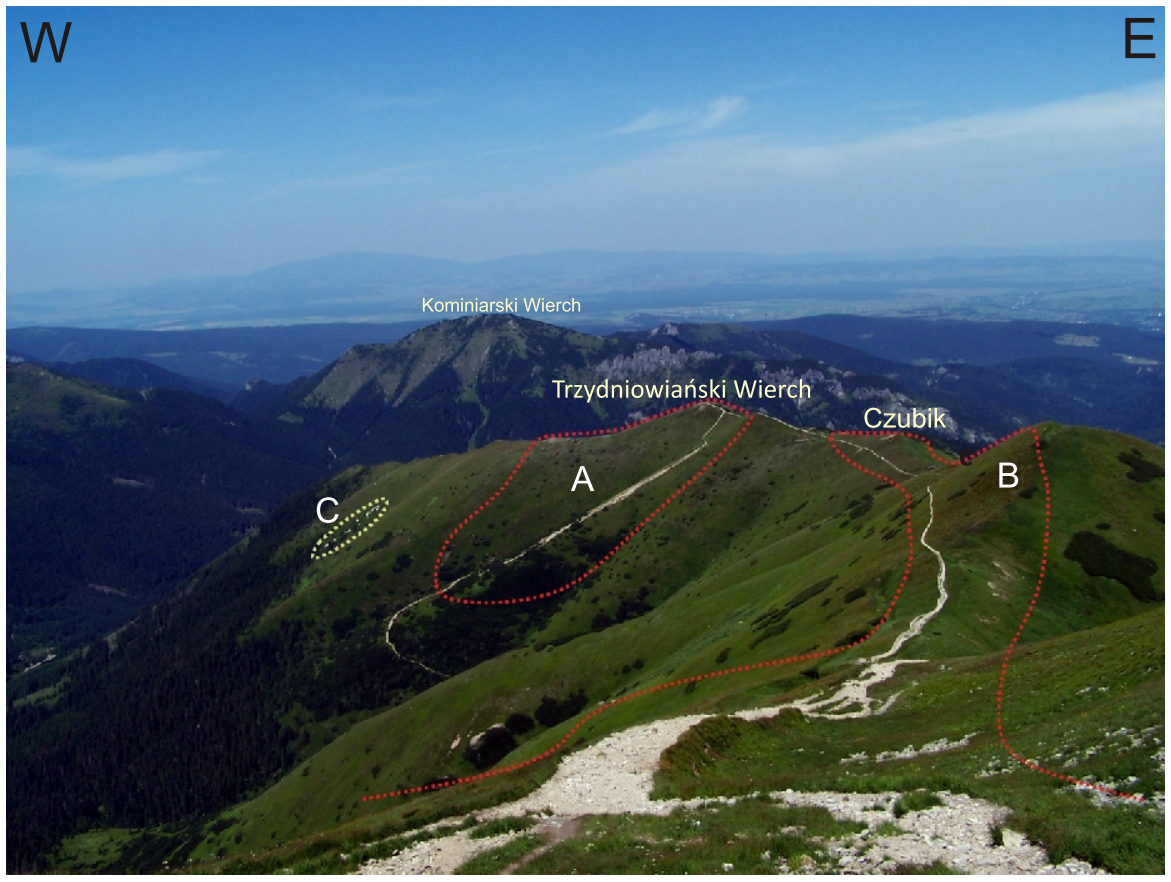

Fig. 12. The general view of domain no. 4 from the Kończysty Wierch Mt. to the north

A - gneisses with brittle shearing overprint; $\mathbf{B}$ - leucogranites with protocataclasis and cataclasites with remnants of ductile structures; $\mathbf{C}$ - outcrops of massive quartz veins
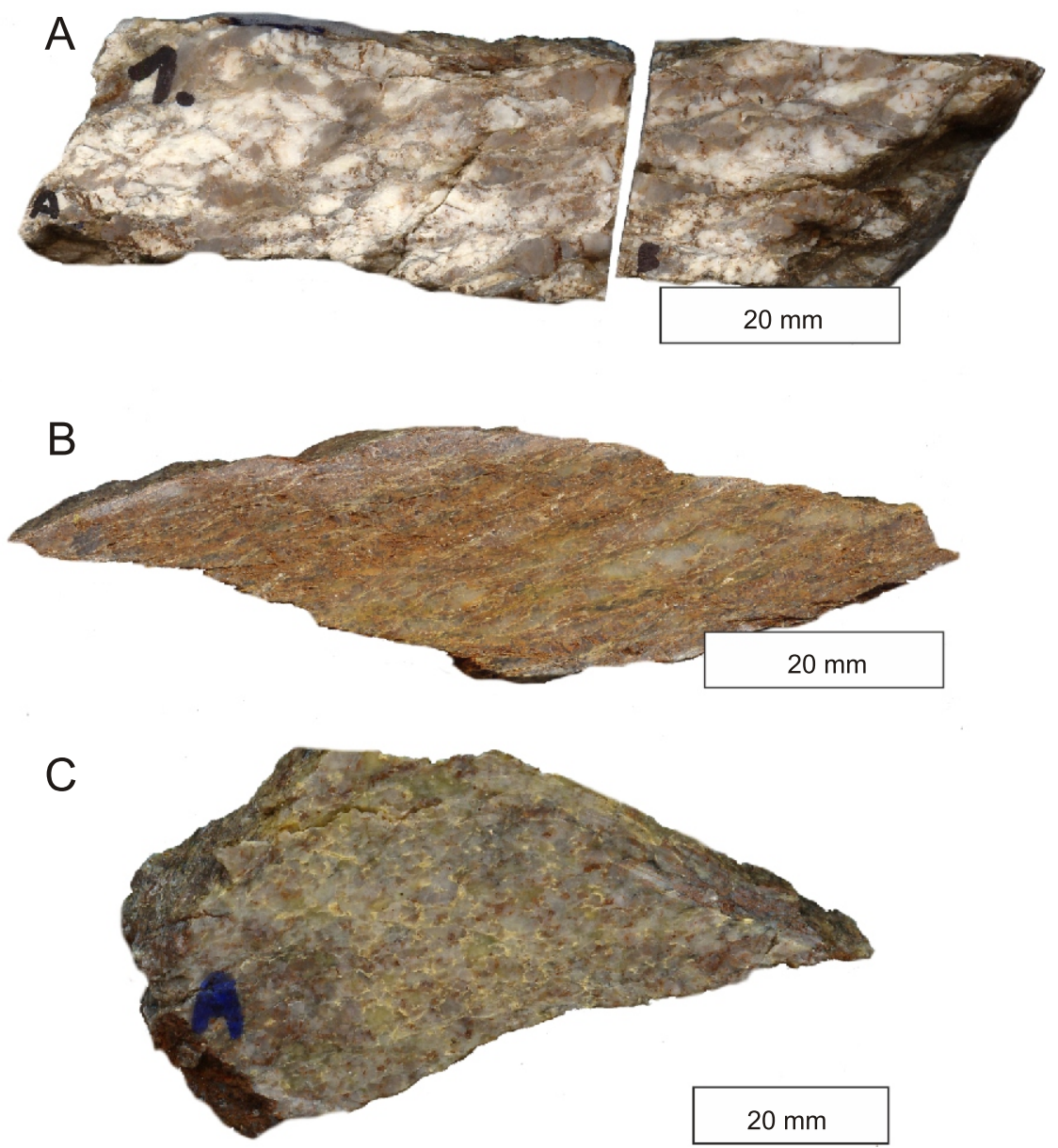

Fig. 13. Examples of hand-specimens from domain no. 4

A - leucogranite from the Czubik Mt. area with brittle deformation; $\mathbf{B}$ - mylonite from the Trzydniowański Wierch Mt. with clear S-C-foliation (dextral sense of shearing); C protomylonite from the Trzydniowański Wierch Mt. 

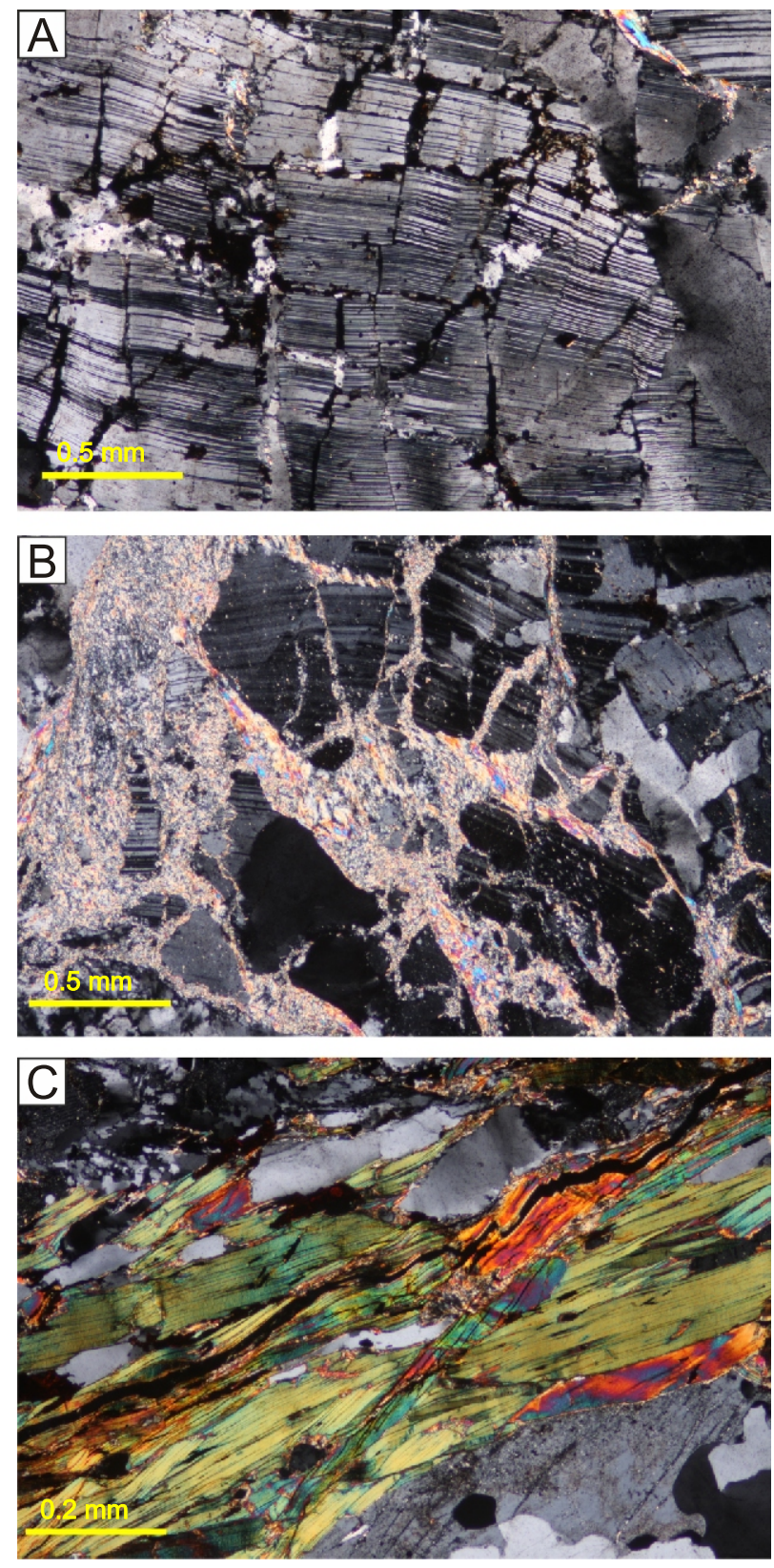

Fig. 14. Examples of microstructures from domain no. 4

A - cracked and partially bended plagioclases in leucogranite from the Czubik Mt.; B - more advanced cataclasis than in photo A, with abundance of the cataclastic matrix; C - C'-type shear band cutting mylonitic foliation in gneiss from the Trzydniowiański Wierch Mt. (sinistral sense of shearing)

Kinematics. There are two distinctive sets of brittle shearing. The first one is characterized by thrust faults dipping at moderate angles mainly to the $\mathrm{N}$, with top-to-the-SE sense of shearing. The second set embraces mostly S-dipping faults with the N-NW direction of tectonic transport.

The $\mathrm{C}$ planes in the mylonitic foliation have different dip azimuths in the range NNE-E-SSE with moderate to steep angles. The S planes dip to the SE at moderate angles. The interpretation of these relationships is difficult, but top-to-the-SW tectonic transport direction seems to be dominant among ductile structures in this domain (Fig. 15).

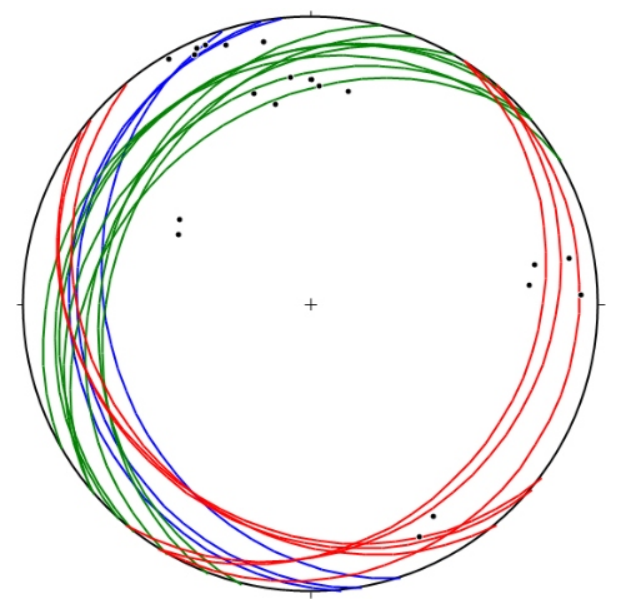

Fig. 15. The orientation of S-foliation planes (red arcs), C-foliation planes (blue arcs), C' shear bands (green arcs) and mineral grain lineation (points) in domain no. 4

\section{QUANTITIVE DETERMINATION OF THE STRUCTURE SHAPE-PREFFERED ORIENTATION}

Table 4 shows the concentration coefficient of samples in which morphometrical analysis was done. The coefficient values vary between 13 and $82 \%$. The minimal value was observed in the ultracataclasite from the Długi Upłaz. Higher values are observed in some leucogranites: 40\% (Łuczniańska Pass sample). This is related to the magmatic foliation developed during anatexis, as well as to the inherited older foliation. Similar coefficients are observed in most of cataclasites, however, the presence of monoclinic structures (S-C cataclasites) makes the coefficient higher $(L>50 \%)$. The highest values are

Table 4

Concentration coefficents $(L)$ of the relative grain orientations in selected samples

\begin{tabular}{|l|c|c|c|}
\hline \multicolumn{1}{|c|}{ Rock name } & $\begin{array}{c}\text { Texture } \\
\text { type }\end{array}$ & $\begin{array}{c}\text { Location } \\
\text { (structural domain) }\end{array}$ & $L$ [\%] \\
\hline leucogranite & A1 & Łuczniańska Pass (1) & 37 \\
\hline cataclastic breccia & A2 & Wołowiec Mt.(3) & 46 \\
\hline protocataclasite & A2 & Kończysty Wierch Mt. (4) & 29 \\
\hline protocataclasite & A2 & Wołowiec Mt. (3) & 37 \\
\hline protocataclasite & C2 & $\begin{array}{c}\text { Trzydniowiański Wierch } \\
\text { Mt. (4) }\end{array}$ & 48 \\
\hline mesocataclasite & A2 & Długi Upłaz (1) & 71 \\
\hline mescocataclasite & C3 & Dziurawa Pass (3) & 35 \\
\hline ultracataclasite & A3 & Długi Upłaz (1) & 13 \\
\hline ultracataclasite & B4 & Zabrat' Pass (2) & 33 \\
\hline protomylonite & C2 & Wołowiec Mt. (3) & 50 \\
\hline mesomylonite & D3 & Zabrat' Pass (2) & 61 \\
\hline ultramylonite & C4 & Długi Upłaz (1) & 71 \\
\hline ultramylonite & D4 & Zabrat' Pass (2) & 82 \\
\hline
\end{tabular}

The textural types are defined in Kania (2014) 
observed in mylonites, up to $82 \%$ in the Zabrat Pass ultramylonite, where porphyroclasts are elongated and oriented along the foliation.

\section{DISCUSSION}

Taking into account the type of structures correlated with the protolith rock, the following four structural types of shear zones can be distinguished in the discussed area (Fig. 16):

- The 1st type shear zones with structures developed only in the ductile conditions. These are mainly meso- to ultramylonites, often with high mica content (the term "phyllonite" (Brodie et al., 2007) seem to be useful for rocks with high mica content and dense foliation planes). The characteristic feature is that the zones are now located mainly on mountain passes (Łuczniańska, Zabrat', Dziurawa).

- The 2nd type zones that developed in the brittle-ductile conditions. These zones form large packets, formed by various types of shearing-related rocks (but mainly proto- to mesomylonites, and cataclasites). The characteristic feature is the density of mesofaults, at some places even above 100 planes per a 1 metre profile. Two examples in the investigated area are the Litworowy Couloir and the Wołowiec Mt. massif.

- The 3rd type shear zones which are developed in the brittle regime of deformation, but preserve some features of earlier deformation, like mica fish. These types of shear zones are characteristic for the marginal areas of thrust sheets, and occur in the vicinity of non-deformed leucogranites on the Czubik Mt.

- The 4th type shear zones with only weak to moderate brittle deformation (mainly proto-, sometimes mesocataclasites). These zones occur mainly in the northern parts of domains no. 1 and no. 4, i.e. the Długi Upłaz and the Trzydniowiański Wierch Mt. However, even these rocks show moderate, but significant shape-preferred orientation of grains.

The list above can be upgraded by adding gneisses which, obviously, were sheared, however, these form massifs rather than limited localized shear zones.

The interesting problem is the relationships between shear zone types listed above and the lithology of rocks which underwent shearing-related dynamic metamorphism. Such correlation is problematic due to the fact that numerous protolith lithologies occurred in this area. The variability of structures often observed on the thin section scale makes modal minera analyses mostly unusable for determination of the protolith. However, location of the shear zones, and their spatial relationships, allows to formulate the following observations:

- the 1st type shear zones are metamorphic schists, which probably have not undergone advanced later deformation;

- the 2nd type shear zones seems to be developed mainly from granodiorites, probably as an effect of their shearing;

- the 3rd type shear zones are gneisses or granitic gneisses which underwent later deformation in the brittle conditions;

- the 4th type shear zones are leucogranites which have not been deformed under ductile conditions, however brittle deformation is clearly visible, and observed shape-preferred orientation marks a non-coaxial deformation regime.
This overview indicates advanced deformation partitioning - which means a subdivision of deformation into domains with different deformation patterns (Passchier and Trouw, 2005) - of the Western Tatra crystalline core, corresponding with the deformed rock type. The ductile shear zones were later reactivated, however, new brittle and brittle-ductile shear zones were also created forming a complex lithological structure. The rate of deformation was different in different parts of the complex (Kania, 2014). Brittle reworking of the older ductile structures could lead to the formation of tectonic melange zones, however, in most cases it seems that the older discontinuities were the basis for similarly (but not exactly the same) oriented brittle shear zones. This disorientation is typical when taking into account reactivation of the shear zones (Bons et al, 2012).

The idea of two inverted metamorphic structural units (Janák, 1994; Gawęda, 2001; Gawęda and Burda, 2004) seems to be too much simplified. Especially, the interpretation of the upper parts of the Długi Upłaz Ridge and of the Wołowiec Mt. as a migmatite upper structural unit, as it was shown on the map by Gawęda (2001), might need some reconsideration. Migmatites are not very common in this area and are not marked on the older maps (e.g., Bac-Moszaszwili et al., 1979) where leucogranites (called "alaskites" there) and mylonites dominate, whilst other metamorphic rocks (gneisses, schists, probably also amphibolites) occur sporadically. The complicated structure is not only due to the diversity of protoliths (leucogranites, which are a product of anatexis of earlier deformed rocks (orthogneisses), Rohače-type granodiorites, and metamorphic rocks, but also due to the diversity of multi-stage deformation products.

The most prominent shear zones are those of the 2nd type. In the study area they form two packets of shearing-related rocks, up to hundreds of metres wide. The first one cuts the Długi Upłaz Ridge, and forms deformational complexes in the Litworowy Couloir, outcropped at altitudes of ca. 1400-1500 m. The second one is the upper part of the Wołowiec Mt. massif, above an altitude of ca. $1800 \mathrm{~m}$. From the structural point of view, this is the upper wall of the Wołowiec Mt. overthrust (Cymerman, 2011). This wall has a form of a strongly heterogeneous complex of fault rocks, formed in a brittle and brittle-ductile compressional regime. The compression resulted in the formation of numerous hierarchical tectonic flakes. Within the massif, the fault rock lithology varies vertically (protocataclasites near the Wołowiec Mt. summit, meso- and ultracataclasites below), as well as laterally (increasing grade of deformation intensity southwards). The vertical gradient, perpendicular to the thrust plane is interpreted as an effect of the decreasing deformation intensity in the damage zone of the Wołowiec Mt. overthrust (Childs et al., 2009). The horizontal (subhorizontal) gradient can be linked with the proximity of the Wołowiec Mt. overthrust margin.

The structures and the interpreted process described above are correct also for the Długi Upłaz with the Litworowy Couloir. The sequence of fault rocks in the Litworowy Couloir (cataclasites, S-C cataclasites, mylonites) resembles the sequence observed on the western slopes of the Wołowiec Mt. The observed fault rock complexes should be considered as shear zones parallel to the thrusting planes of tectonic flakes in the crystalline core. The complex internal structure of such zones was underlined by Żelaźniewicz (1996); however, he had not discussed the diversity of the fault rock present in these zones.

The characteristic feature observed is the presence of quartz and pegmatite veins near the mylonitic schist zones. At least four such zones were found between the Łuczniańska Pass and the Rakon Mt. Cymerman (2009) linked the presence 


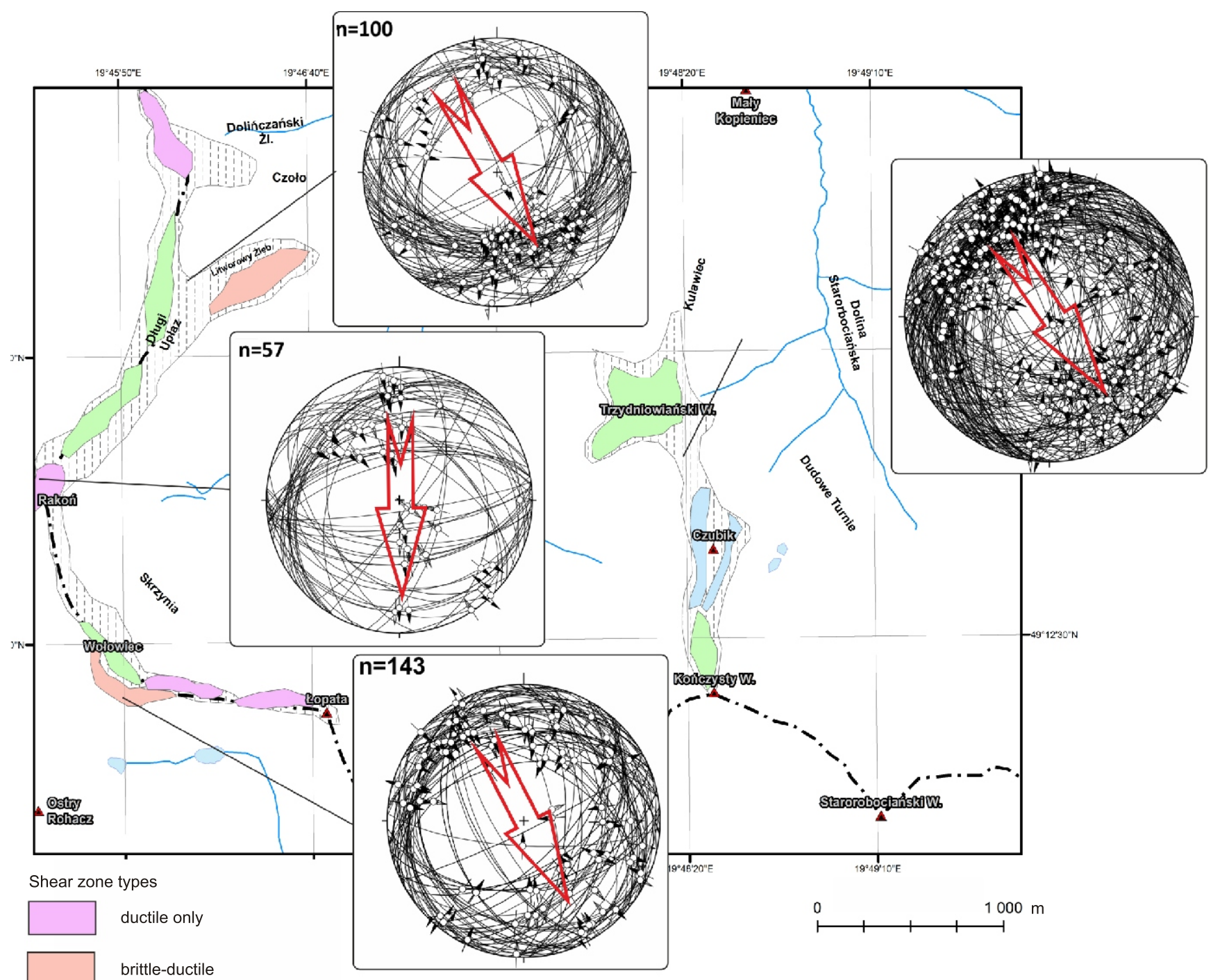

brittle overprinted on ductile

brittle only

Fig. 16. Sketch-map of the dominant types of shearing zones and orientation of mesofaults in the selected areas (Angelier's diagrams, lower hemisphere, equal-area projection; red arrows marks mean tectonic transport direction)

For further explanations see text

of the white quartz veins (so-called "gooses") with shearing and thrusting zones. On the other hand, Gawęda (2001) stated that pegmatites occur in the core parts of folds. This is obviously normal situation in shear zones (Hudleston, 1989), however, laminated veins seem to be rather a product of silica transport and deposition along shear zones, especially at the contact between hardened and softened zones, as it was described earlier.

The fault rock complex of the Trzydniowiański Wierch Mt. with two types of shear zones (3rd and 4th) can be interpreted as a product of low-angle overthrusting of the leucogranitic flake over the granitic gneisses. Such a structure can be interpreted also as developed during syntectonic anatexis when the melt forms leucogranitic veins, and gneisses form the restite. The stress was mainly accommodated by deformation of the older ductile deformation zones in the granitic gneisses. The upper, leucogranitic, packet shows signs of magmatic syntectonic foliation. Subsequently, leucogranites underwent only weak to moderate brittle deformation, resulting mainly in the formation of some breccias and protocataclasites.

The analysis of the kinematics of non-coaxial brittle shearing structures - Y-P-R fault systems (Katz et al., 2004), documented sense of shearing top-to-the-SE, S and SW (Fig. 16). The most common sense of shearing recorded by the ductile or brittle-ductile kinematic indicators is top-to-the-NW and W. Similar senses of shearing were observed also in the other areas of the Western Tatra Mts., e.g. on the Łopata Mt., the Niska Pass and on the Jarząbczy Wierch Mt. (Cymerman, 2011). It indicates that the movement field during brittle deformation processes was relatively homogenous in the whole Western Tatra Mts. crystalline core. The deformation processes were intense, as proved by thick complexes of fault rocks on the Wołowiec Mt. 
or in the Litworowy Couloir. The grain shape indicators analysis of the fault rocks in the Western Tatra Mts. (Kania, 2014) suggests this was a long process, below the feldspar plasticity limit, but with dynamic recrystallisation of quartz and intense sericitisation of feldspars.

The dominant products of brittle deformation in the described area are complexes of protocataclasites and some mesocataclasites formed during a block-controlled cataclastic flow (Ismat and Mitra, 2005; Kania, 2014). The presence of brittle regime-related kinematic indicators, as well as measured shape-preferred orientation, marks a non-coaxial character of these processes.

The mylonites observed in the study area are mainly low-grade mylonites, as they are defined by Trouw et al. (2010), with the following distinctive features: crystal-plastic deformation of quartz, elongated shapes, undulose extinction, and sometimes bulging recrystallisation (BLG). At some places, subgrain recrystallisation aggregates are present, but more likely is that there are effects of a decreasing strain rate instead of increasing temperature (Hirth and Tullis, 1992). Feldspars underwent mainly brittle deformation, with some crystal-plastic structures. Common occurrences of asymmetric kinematic indicators (like muscovite fish), as well as sharp transitions between textural types (Fig. 6D) also mark the low-grade mylonites that formed in the temperature range between 250 and $500^{\circ} \mathrm{C}$ (Trouw et al., 2010).

The most intriguing problem is time relationships between the described shear zones. In lacking good geochronological data, it is still possible to make some conclusions. According to the four shear zone types listed at the beginning of this discussion:

- The 1st type shear zones represent only ductile deformation, which can be interpreted as a Variscan metamorphism product. The reactivation of these zones cannot be excluded, however, there are no clear evidences for this.

- The 2nd type shear zones represent ductile and brittle-ductile shearing, mainly in granodiorites. The Alpine age of the older structures seems possible.

- The 3rd type shear zones are Variscan gneissic rocks which underwent later (Alpine) brittle deformation.

- The 4th type shear zones are leucogranites, and their brittle deformation can be of the same age as in the $3 \mathrm{rd}$ type. However, these rocks show no ductile deformation due to later leucogranite emplacement, other than metamorphism of gneisses. In fact, these leucogranites are a product of Variscan anatexis with Alpine brittle deformation.

The question arises if ductile-brittle deformation can be not only Variscan but also Alpine in age. Analysis of the available data shows that during the Alpine orogeny there were the following stages with conditions favourable for brittle and ductile-brittle deformation, as well as for hydrothermal processes (Fig. 17):

1. Upper Cretaceous eo-Alpine metamorphism with conditions for mylonitisation at 140-120 Ma (Maluski et al., 1993) and intense compressional tectonics (Jurewicz, 2005).

2. Cretaceous and Cretaceous/Paleogene boundary with probable mylonitisation (or phyllonitisation) episodes at 89-85 Ma and $66 \mathrm{Ma}$ (Maluski et al., 1993).

3. Eocene-Oligocene compressional stage (Lefeld, 2009), with the beginning of uplift marked with pseudotachylyte generation (Kohút and Sherlock, 2003).

4. Rotational uplifting of the Tatra block during the Miocene (Jurewicz, 2005).

The temperature of the Tatra massif exceeded $100^{\circ} \mathrm{C}$ in the Palaeogene and even in the Miocene (Kovač et al., 1994; Anczkiewicz, 2005; Anczkiewicz et al., 2013), which means conditions favourable for hydrothermal activity. The young hydrothermal activity is proved also by dating of clay minerals from the so-called "clay pockets", containing fault gauges in the High Tatra Mts. (Kuligiewicz, 2011). The Tatra massif may have been additionally warmed up during Miocene magmatism in the Central Western Carpathians (e.g., Danišík et al., 2008, 2010, 2012). Moreover, the cooling of the Tatra Mts. was slower in their western part, due to the westward plunging of the Miocene rotation axis (Jurewicz, 2005). These data support the thesis of the role of the hydrothermal process in the formation of different deformation complexes (strain softening and strain hardening subzones of the parent shear zones; Kania, 2014). The role of the greisenisation process, earlier postulated by Skupiński (1975), was not so important, however, it was observed. The question is if it was really "tectonic greisenisation", as Skupiński wrote, or just small-scale greisenisation along some of the shear zones, which seems to be more likely due to lack of structure-connected greisenisation evidences.

On the other hand, there are opinions (Żelaźniewicz, 1996) that mylonites are of a Variscan age and could be overprinted by Alpine processes. This is not probable, especially when regarding a general southward sense of shear marked by ductile kinematic indicators. Nonetheless, the shear zones dominated by brittle-ductile deformation may have been formed mainly during the Alpine orogeny and inherited some of the Variscan features at that time.

The applied method of statistical determination of the shape-preferred orientation allows the recognition of directional features even in non-foliated rocks. However, the shape-preffered orientation of an aggregate reflects long-time and multistage history of the deformation, so it is not an indicator of the mean or late stage kinematics (Stahr and Law, 2014). In fact, if $37 \%$ value was achieved in the syntectonic anataxesis of the leucogranite, lower values (observed in one of the cataclasites) could be interpreted as an effect of disintegration and then chaotic disorientation of grains during cataclasis. On the other hand, the higher values were achieved during non-coaxial shearing processes in the cataclasites, as well as mylonites.

The interesting question should be a comparison of the brittle structures developed in the crystalline rocks and those in Triassic quartzites (Seisian) of Tatricum. Some preliminary data shows that the orientation of the dominant fault set on the Długi Upłaz Ridge (Fig. 16) is similar to the one set of joints observed in quartzite at the Upalone site. This problem needs further in-depth investigation.

The fault plane orientations and shear sense recorded in the brittle structures (Fig. 16) are characteristic for the Alpine orogeny processes, being an effect of the ALCAPA terrain migration to the north (Csontos and Vörös, 2004). However, the complicated and non-unambiguous pattern of brittle kinematics is an effect of the location on the NW corner of the Alpine-Carpathian mountain belt as well as of thrusting processes in the autochthonous basement of the Western Carpathians (Jarosiński, 2011). Yet, this interpretation applies only to sets of mesofaults, and is just a part of the complicated kinematic and structural overview of the Western Tatra crystalline massif. 


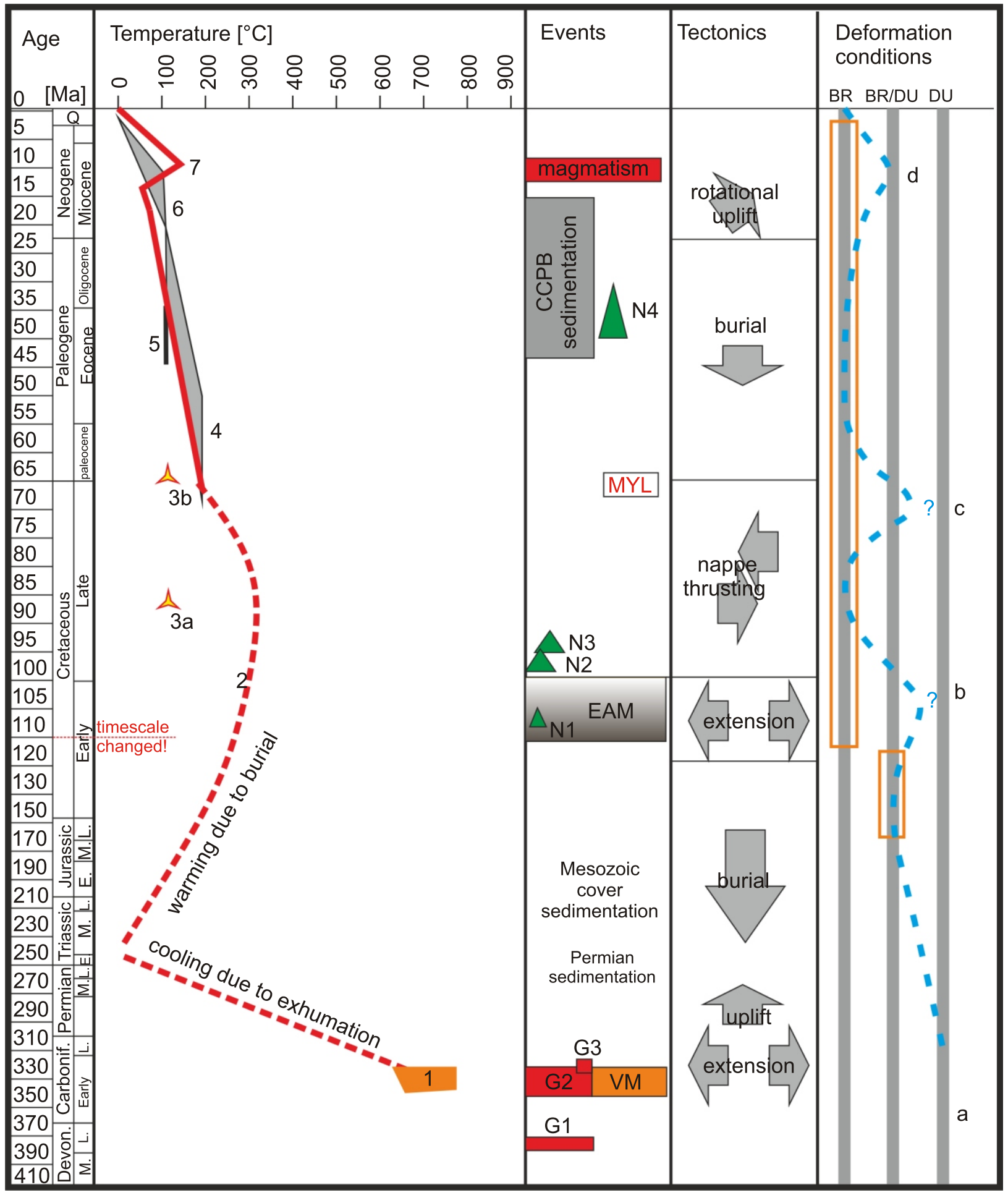

Fig. 17. Compiled scheme of the Tatricum tectono-metamorphic evolution

Temperatures: 1 - maximum of the Variscan metamorphism (Poller et al., 2000; Gawęda and Burda, 2004); 2 - eo-Alpine metamorphism (Danišík et al., 2011, 2012); 3a, b - Ar/Ar dating (Maluski et al., 1993); 4 - Tatricum cooling (Kovač et al., 1994); 5 - apatite fission track dating (Burchart, 1972); 6 - cooling field of the Tatra massif, FT dating (Anczkiewicz, 2005), 7 - Miocene temperature rising (Danišík et al., 2012). Geological events: G1 - granitoid intrusion, protolith for gneisses (Poller et al., 2000); G2 - Rohače granodiorite intrusion (Poller et al., 2000); G3 - leucogranite syntectonic formation (Gaweda, 2001); VM - main stage of the Variscan metamorphism (Poller et al., 2000; Gawęda and Burda, 2004); EAM - eo-Alpine metamorphism (Danišík et al., 2011, 2012); N1 Choč unit overthrusting, N2 - Križna unit overthrusting (Jurewicz, 2005); N3 - eo-Alpine overthrusting (Danišík et al., 2012); N4 Eocene/Oligocene overthrusting (Lefeld, 2009); MYL - Alpine mylonites generation (Maluski et al., 1993). Tectonic phases according to Jurewicz (2005). Deformation conditions: BR - brittle, BR/DU - brittle-ductile, DU - ductile, orange bars - pre-Alpine stage of brittle-ductile deformation and Alpine stage of brittle deformation according to Jurewicz and Bagiński (2005); blue line - interpreted conditions of deformation in the Western Tatra Mts.: $a$ - Variscan ductile deformation, $b$ - more ductile conditions during the eo-Alpine metamorphism, $\mathrm{c}$ - formation of Alpine mylonites, $\mathrm{d}$ - more ductile conditions during the Miocene thermal event 


\section{CONCLUSIONS}

1. The shear zones take a key role in the Western Tatra crystalline massif structure. Numerous heterogeneous, generally sub-horizontally oriented shear zones were developed during mainly non-coaxial shearing of different protholitic rocks.

2. Four types of shear zones have been distinguished: (1) ductile shear zones in gneisses, (2) brittle-ductile complex shear zones, (3) ductile mylonitic shear zones in gneisses with clear later brittle deformation overprinted, (4) brittle shear zones developed in leucogranites after their anatectic formation.

3. These shearing deformation processes were long-lasting with the development of different asymmetric structures at dif- ferent levels and probably at different times. The brittle structures are in general younger than the ductile ones, the strain partitioning was crucial in the formation of the shear zones.

4. The shear sense recorded by the structures formed in the ductile conditions is different from the main ductile-brittle and brittle regime of deformation.

Acknowledgements. I am especially grateful to $\mathrm{M}$. Kohút and $Z$. Cymerman, the reviewers of this paper, for their remarks and advices. I thank the Directorate of the Tatra National Park for the permission to conduct fieldwork. The study was financed by the Jagiellonian University funds for young scientists, and was part of my Ph.D. thesis.

\section{REFERENCES}

Anczkiewicz, A., 2005. Cenozoic uplift of the Tatra and Podhale Basin from the perspective of the apatite fission track analyses. Polskie Towarzystwo Mineralogiczne. Prace Specjalne, 25: 261-264.

Anczkiewicz, A., Środoń, J., Zattin, M., 2013. Thermal history of the Podhale Basin in the internal Western Carpathians from the perspective of apatite fission track analyses. Geologica Carpathica, 64: 141-151.

Bac-Moszaszwili, M., Burchart, J., Głazek, A., Iwanow, A., Jaroszewski, W., Kotański, Z., Lefeld, J., Mastella, L., Ozimkowski, P., Roniewicz, P., Skupiński, A., Westwalewicz-Mogilska, E., 1979. Geological map of the Polish Tatra Mountains (in Polish with English descriptions). Wyd. Geol., Warszawa.

Berthé, D., Choukroune, P., Jegouzo, P., 1979. Orthogneiss, mylonite and non-coaxial deformation of granites: the example of the South Armorican Shear Zone. Journal of Structural Geology, 1: $31-42$.

Bons, P., Elburg, M., Gomez-Rivas, E., 2012. A review of the formation of tectonic veins and their microstructures. Journal of Structural Geology, 43: 33-62.

Brodie, K., Fettes, D. Harte, B., Schmid, R., 2007. Structural terms including fault rock terms. Recommendations by the IUGS Subcomission on the Systematics of Metamorphic Rocks. Web version of 01.02.07. http://www.bgs.ac.uk/scmr/docs/papers/paper_3.pdf [15.07.2013]

Burchart, J., 1972. Fission-track age determinations of accessory apatite from the Tatra Mountains, Poland. Earth and Planetary Science Letters, 15: 418-422.

Burda, J., Gawęda, A., 2009. Shear-influenced partial melting in the Western Tatra metamorphic complex: geochemistry and geochronology. Lithos, 110: 373-385.

Burda, J., KIötzli, U., 2007. LA-MC-ICP-MS U-Pb zircon geochronology of the Goryczkowa type granite - Tatra Mts., Poland. Prace Specjalne PTMin, 31: 89-92.

Burda, J., Gawęda, A., KIötzli, U., 2013. U-Pb zircon age of the youngest magmatic activity in the High Tatra granites (Central Western Carpathians). Geochronometria, 40: 134-144.

Chen, Y., Jiang, D., Zhu, G., Xiang, B., 2014. The formation of mica fish: A modeling investigation based on micromechanics. Journal of Structural Geology, 68: 300-315.

Childs, C., Manzocchi, T., Walsh, J., Bonson, C., Nicol, A., Schapfer, M., 2009. A geometric model of fault zone and fault rock thickness variations. Journal of Structural Geology, 31: 117-127.

Csontos, L., Vörös, A., 2004. Mesozoic plate tectonic reconstruction of the Carpathian region. Palaeogeography, Palaeoclimatology, Palaeoecology, 210: 1-56.
Cymerman, Z., 1989. Determination of the sense shear (in Polish with English summary). Przegląd Geologiczny, 37: 605-613.

Cymerman, Z., 2009. Tektonika alpejska waryscyjskiego krystaliniku Tatr Zachodnich - przykłady od Łuczniańskiej Przełęczy po NW zbocza Wołowca - Wycieczka terenowa A5 (in Polish). In: LXXIX Zjazd Polskiego Towarzystwa Geologicznego "Budowa geologiczna Tatr i Podhala ze szczególnym uwzględnieniem zjawisk geotermalnych na Podhalu", Bukowina Tatrzańska, 26-29 września 2009, materiały konferencyjne: 121-133.

Cymerman, Z., 2011. Zlokalizowane strefy ścinania w skałach krystalicznych na obszarze polskiej części Tatr Zachodnich (in Polish). In: Tatrzańskie Warsztaty Geologiczne (eds. T. Rychliński and P. Jaglarz): 20-49, Zakopane, 13-16 października 2011.

Danišík, M., Kohút, M., Dunkl, I., Frisch, W., 2008. Thermal evolution of the Žiar Mts. basement (Inner Western Carpathians, Slovakia) constrained by fission track data. Geologica Carpathica, 59: 9-30.

Danišík, M., Kohút, M., Broska, I., Frisch, W., 2010. Thermal evolution of the Malá Fatra Mountains (Central Western Carpathians): insights from zircon and apatite fission track thermochronology. Geologica Carpathica, 61: 19-27.

Danišík, M., Kadlec, J., Glotzbach, C., Weisheit, A., Dunkl, I., Kohút, M., Evans, N., Orvošová, M., McDonald, B., 2011 Tracing metamorphism, exhumation and topographic evolution in orogenic belts by multiple thermochronology: a case study from the Nizke Tatry Mts., Western Carpathians. Swiss Journal of Geosciences, 104: 285-298.

Danišík, M., Kohút, M., Evans, N., McDonald, B., 2012. Eo-Alpine metamorphism and the "mid-Miocene thermal event" in the Western Carpathians (Slovakia): New evidence from multiple thermochronology. Geological Magazine, 149: 158-171.

Deditius, A., 2004. Characteristics and isotopic age of the muscovite blastesis from the mylonitic zones in the crystalline rocks of the Western Tatra Mountains (in Polish with English summary). Prace Naukowe Uniwersytetu Śląskiego, 16: 121-150.

Fritz, H., Neubauer, F., Janák, M., Putiš, M., 1992. Variscan mid-crustal thrusting in the Carpathians II: kinematics and fabric evolution of the Western Tatra basement. Terra Abstract, Supplement 2 to Terra Nova, 4: 24 .

Gawęda, A., 2001. Alaskites of the Western Tatra Mountains. A record of Early-Variscan collision stage in the Carpatians pre-continent (in Polish with English summary). Wydawnictwo Naukowe Uniwersytetu Śląskiego, Katowice.

Gawęda, A., 2007. Variscan granitoid magmatism in Tatra Mountains - the history of subduction and continental collision. AM Monograph, 1: 319-332. 
Gawęda, A., 2008. An apatite-rich enclave in the High Tatra granite (Western Carpathians): petrological and geochronological study. Geologica Carpathica, 59: 295-306.

Gawęda, A., Burda, J., 2004. Evolution of the metamorphism and deformations in the crystalline complex of the Western Tatra Mountains (in Polish with English summary). Prace Naukowe Uniwersytetu Śląskiego, 16: 53-184.

Gawęda, A., Doniecki, T., Burda, J., Kohút, M., 2005. The petrogenesis of quartz-diorites from the Tatra Mountains (Central Western Carpathians): an example of magma hybridization. Journal of Mineralogy and Geochemistry, 181: 95-109.

Grotenhuis, S.M., Trouw, R.A.J., Passchier, C.W., 2003. Evolution of mica fish in mylonitic rocks. Tectonophysics, 372: 1-21.

Guzik, K., 1959. Szczegółowa Mapa Geologiczna Tatr, 1:10 000, arkusz B1, Bobrowiec (in Polish). Wyd. Geol., Warszawa.

Halfpenny A., Prior, D.J., Wheeler, J., 2006. Analysis of dynamic recrystallization and nucleation in a quartzite mylonite. Tectonophysics, 427: 3-14.

Hirth, G., Tullis, J., 1992. Dislocation creep regimes in quartz aggregates. Journal of Structural Geology, 14: 145-160.

Hudleston, P., 1989. The association of folds and veins in shear zones. Journal of Structural Geology, 11: 949-957.

Ismat, Z., Mitra, G., 2005. Folding by cataclastic flow: evolution of controlling factors during deformation. Journal of Structural Geology, 27: 2181-2203.

Janák, M., 1994. Variscan uplift of the crystalline basement, Tatra Mts., central western Carpathians: evidence from ${ }^{40} \mathrm{Ar} /{ }^{39} \mathrm{Ar}$ laser probe dating of biotite and P-T-t paths. Geologica Carpathica, 45: 293-300.

Jarosiński, M., 2011. Współczesne naprężenia tektoniczne w polskich Karpatach i na ich przedpolu: czy strefa szwu kolizyjnego jest mechanicznie spójna (in Polish)? In: IX Ogólnopolska konferenecja z cyklu "Neotektonika Polski" Neotektonika Karpat i Polski pozakarpackiej: podobieństwa i różnice (ed. W. Zuchiewicz): 25-26, Kraków, 24-25 czerwca 2011.

Jiang, D., 2014. Structural geology meets micromechanics: A self-consistent model for the multiscale deformation and fabric development in Earth's ductile lithosphere. Journal of Structural Geology, 68: 247-272.

Jurewicz, E., 2005. Geodynamic evolution of the Tatra Mts. and the Pieniny Klippen Belt (Western Carpathians): problems and comments. Acta Geologica Polonica, 55: 295-338.

Jurewicz, E., Bagiński, B., 2005. Deformation phases in the selected shear zones within the Tatra Mountains granitoid core. Geologica Carpathica, 56: 17-28.

Kahan, Š., 1962. Eine neue Ansicht über den geologischen Aufbau des Kristallinikums der West Tatra (in German). Acta Geologica et Geographica Universitatis Comenianae, 12: 115-122.

Kania, M., 2012. The structure and the evolution of the Alpine age shear zones in the crystalline core of the Polish part of the Western Tatra Mts. (in Polish with English summary). Unpublished Ph.D. thesis, Jagiellonian University, Kraków.

Kania, M., 2014. Microfabric diversity and grain shape analysis of fault rocks from the selected areas of the Western Tatra Mountains. Geological Quarterly, 58 (1): 3-18.

Katz, Y., Weinberger, R., Aydin, A., 2004. Geometry and kinematic evolution of Riedel shear structures, Capitol Reef National Park, Utah. Journal of Structural Geology, 26: 491-501.

Kohút, M., 2000. Why are alaskites not present in the Slovak part of the Tatra Mountains? Prace Specjalne PTMin, 17: 187-189

Kohút, M., Janák, M., 1994. Granitoids of the Tatra Mts., Western Carpathians: field relations and petrogenetic implications. Geologica Carpathica, 45: 301-311.

Kohút, M., Sherlock, S., 2003. Laser microprobe ${ }^{40} \mathrm{Ar}-{ }^{39} \mathrm{Ar}$ analysis of pseudotachylyte and host-rocks from the Tatra Mountains, Slovakia: evidence for late Palaeogene seismic/tectonic activity. Terra Nova, 15: 417-424.

Kohút, M., Siman, P., 2011. The Goryczkowa granitic type SHRIMP dating of an original granodiorite-tonalite variety. Mineralogia, 38: 113-114.
Kohút, M., Poller, U., Gurk, C., Todt, W., 2008a. Geochemistry and $\mathrm{U}-\mathrm{Pb}$ detrital zircon ages of metasedimentary rocks of the Lower Unit, Western Tatra Mountains (Slovakia). Acta Geologica Polonica, 58: 371-384.

Kohút, M., Uher, P., Putiš, M., Sergeev, S., Antonov A., 2008b Dating of the Lower Carboniferous granitic rocks from the Western Carpathians in the light of new SHRIMP U-Pb zircon data. 7th annual Christmas meeting of SGS (in Slovak). Mineralia Slovaca, 40: 3-4.

Kovač, M., Kral, J., Marton, E., Plašienka, D., Uher, P., 1994. Alpine uplift history of the central western Carpathians: geochronological, paleomagnetic, sedimentary and structural data. Geologica Carpathica, 45: 83-96.

Krawczyk, A., Słomka, T., 1994. Podstawowe metody matematyczne w geologii (in Polish). Wydawnictwo AGH.

Kuligiewicz, A., 2011. Mineralogy of the clay gouges developed in shear zones of the High Tatra Mountains (in Polish with English summary). Unpublished MSc. thesis, Jagiellonian University, Kraków.

Lefeld, J., 2009. Alpine orogenic phases in the Tatra Mts (in Polish with English summary). Przegląd Geologiczny, 57: 669-673.

Lin, A., 1999. S-C cataclasite in granitic rock. Tectonophysics, 304: 257-273.

Lin, A., 2001. S-C fabrics developed in cataclastic rocks from the Nojima fault zone, Japan and their implications for tectonic history. Journal of Structural Geology, 23: 1167-1178.

Lister, G., Snoke, A., 1984. S-C Mylonites. Journal of Structural Geology, 6: 617-638.

Mahel', M., 1986. Geologická stavba československých Karpát/Paleoalpínske jednotky 1 (in Czech). VEDA, Bratislava.

Maluski, H., Rajlich, P., Matte, P., 1993. ${ }^{40} \mathrm{Ar}-{ }^{39} \mathrm{Ar}$ dating of the Inner Carpathians Variscan basement and Alpine mylonitic overprinting. Tectonophysics, 22: 313-337.

Michalik, A., Guzik, K.,1959. Szczegółowa Mapa Geologiczna Tatr, 1:10 000, arkusz C1, Wołowiec (in Polish). Wyd. Geol., Warszawa.

Minaěr, J., Bielik, M., Kovaěc, M., Plasienka, D., Barka, I., Stankoviansky, M., Zeyen, H., 2011. New morphostructura subdivision of the Western Carpathians: an approach integrating geodynamics into targeted morphometric analysis Tectonophysics, 502: 158-174.

Nemčok, J., Bezák, V., Biely, A., Gorek, A., Halouzka, R., Janák, M., Kahan, S., Kotański, Z., Lefeld, J., Mello, J., Reichwalder, P., Rączkowski, W., Roniewicz, P., Ryka, W., Wieczorek, J., Zelman, J., 1994. The geological map of the Tatra Mountains 1:50 000. Státny geologický ústav Dionýza Stúra, Bratislava.

Passchier, C., Trouw, R., 2005. Microtectonics. Springer 2nd, revised and enlarged edition.

Petit, J., 1987. Criteria on the sense of movement on fault surfaces in brittle rocks. Journal of Structural Geology, 9: 597-608.

Piotrowska, K., 2009. Wykaz jednostek strukturalnych Tatr. In: LXXIX Zjazd Polskiego Towarzystwa Geologicznego "Budowa geologiczna Tatr i Podhala ze szczególnym uwzględnieniem zjawisk geotermalnych na Podhalu", Bukowina Tatrzańska, 26-29 września 2009, materiały konferencyjne: 27-28.

Piotrowska, K., Cymerman, Z., Rączkowski, W., Bac-Moszaszwili, M., 2007. Szczegółowa Mapa Geologiczna Tatr 1:10 000, arkusz Góra Rakoń (in Polish). CAG PIG, Warszawa.

Plašienka, D., 1995. Passive and active margin history of the northern Tatricum (Western Carpathians, Slovakia). Geologische Rundschau, 84: 748-760.

Plašienka, D., 2003. Development of basement-involved fold thrust structures exemplified by the Tatric-Fatric-Veporic nappe system of the Western Carpathians (Slovakia). Geodinamica Acta, 16: 21-38.

Poller, U., Todt, W., 2000. U-Pb single zircon data of granitoids from the High Tatra Mountains (Slovakia): implications for the geodynamic evolution. Transactions of the Royal Society of Edinburgh Earth Sciences, 91: 235-243.

Poller, U., Janák, M., Kohút, M., Todt, W., 2000. Early Variscan magmatism in the Western Carpathians: U-Pb zircon data from 
granitoids and orthogneisses of the Tatra Mountains (Slovakia). International Journal of Earth Sciences, 89: 336-349.

Ramsay, J.G., 1980. Shear zone geometry: A review. Journal of Structural Geology, 2: 83-99.

Roduit, N., 2007. JMicroVision: un logiciel d'analyse d'images pétrographiques polyvalent (in French with English summary). Unpublished Ph.D. thesis, Université de Geneve.

Sibson, R., 1977. Fault rocks and fault mechanisms. Journal of the Geological Society, 133: 191-213.

Simpson, C,. Schmid, S., 1983. An evaluation of criteria to deduce the sense of movement in sheared rocks. GSA Bulletin, 94 $1281-1288$.

Skupiński, A., 1975. Petrogenezis and structure of the crystalline core between Ornak and Rohacze, Western Tatra Mts. (in Polish with English summary). Studia Geologica Polonica, 49: 1-105.

Stahr, D., Law, R., 2014. Strain memory of 2D and 3D rigid inclusion populations in viscous flows - What is clast SPO telling us? Journal of Structural Geology, 68: 347-363.

Trouw, R., Passchier, C., Wiersma, D., 2010. Atlas of Mylonites and Related Microstructures. Springer-Verlag, Berlin.

Uchman, A., 2009. Stratygrafia i sedymentologia utworów mezozoiku Tatr i Podhala (in Polish). In: LXXIX Zjazd Polskiego
Towarzystwa Geologicznego "Budowa geologiczna Tatr i Podhala ze szczególnym uwzględnieniem zjawisk geotermalnych na Podhalu", Bukowina Tatrzańska, 26-29 września 2009, materiały konferencyjne: 9-26.

Uhlig, V., 1897. Die Geologie des Tatragebirges. I: Einleitung und stratigraphischer Teil. Denkschrifte der Akademie derf Wissenschaften in Wien, Matematisch-Naturwissenschaftliche Klasse, 64: 643-684.

White, S., 2001. Textural and microstructural evidence for semi-brittle flow in natural flow rocks with varied mica contents. International Journal of Earth Sciences, 90:14-27.

Williams, M., Melis, E., Kopf, C., Hanmer, S., 2000. Microstructural tectonometamorphic processes and the development of gneissic layering: a mechanism for metamorphic segregation. Journal of Metamorphic Geology,18: 41-57.

Woodcock, N., Mort, K, 2008. Classification of fault breccias and related fault rocks. Geological Magazine, 145: 435-440.

Żelaźniewicz, A., 1996. Mylonites in crystalline basement of the Polish Western Tatra Mts. Polskie Towarzystwo Mineralogiczne. Prace Specjalne, 7: 23-26. 